\title{
Episodio de tormentas y lluvias torrenciales en Cataluña durante los días 22 y 23 de octubre de 2019
}

Nota técnica 36 de AEMET

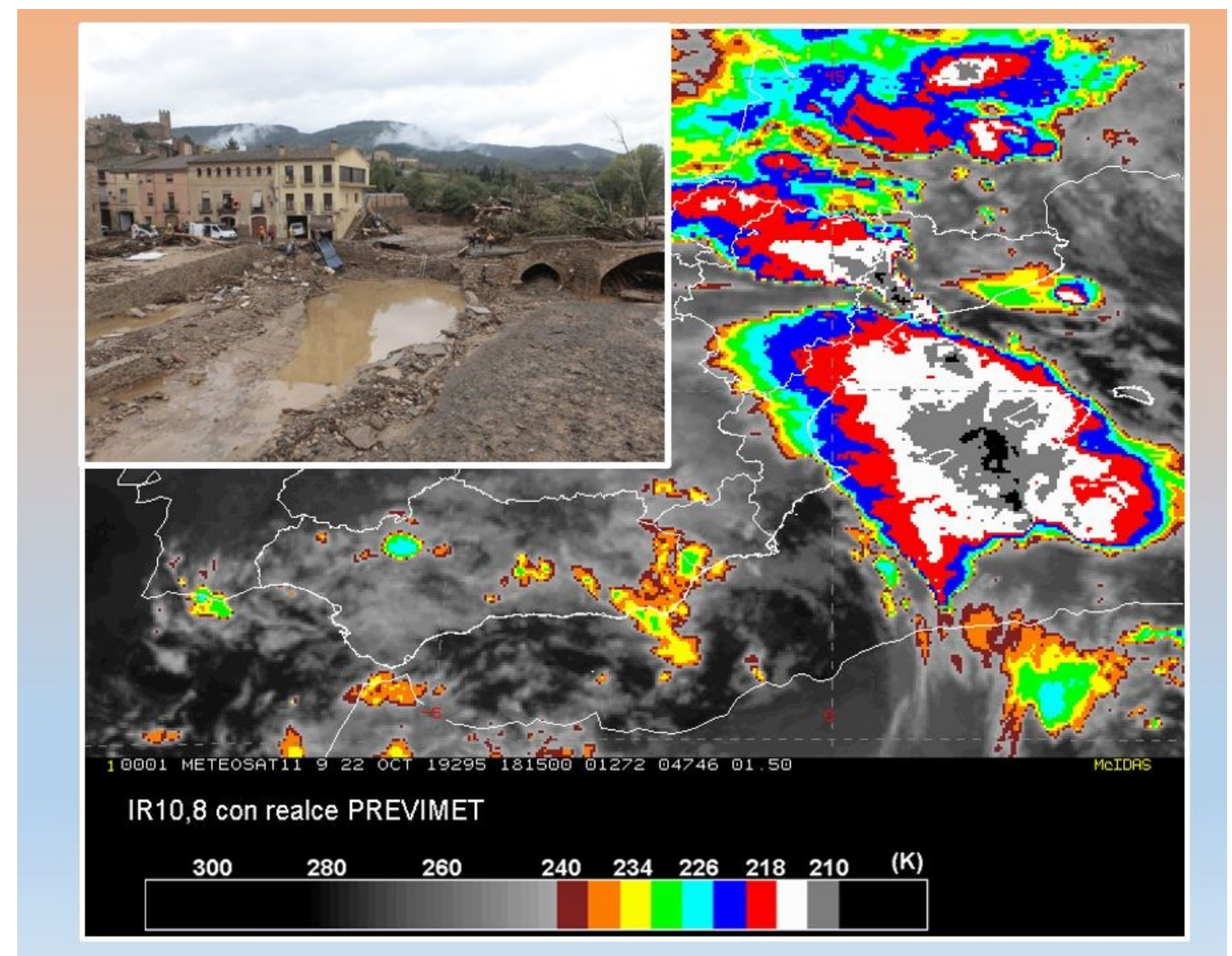

Gabriela Cuevas Tascón

Ramón Pascual Berghaenel 



\section{Episodio de tormentas y lluvias torrenciales en Cataluña durante los días 22 y 23 de octubre de 2019}

Nota técnica 36 de AEMET

Gabriela Cuevas Tascón ${ }^{1}$ (gcuevast@aemet.es)

Ramón Pascual Berghaenel ${ }^{1}$ (rpascualb@aemet.es)

${ }^{1}$ AEMET / Delegación Territorial en Cataluña
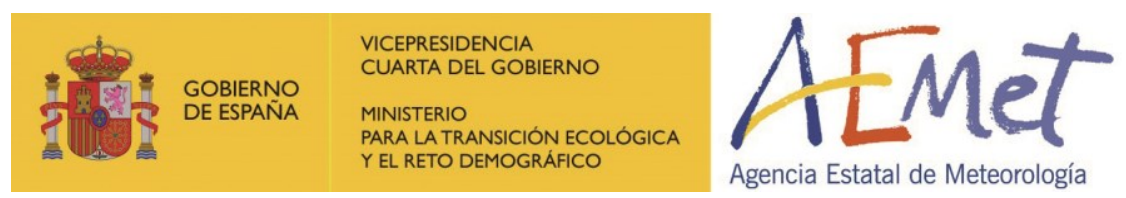
Aviso Legal: los contenidos de esta publicación podrán ser reutilizados, citando la fuente y la fecha, en su caso, de la última actualización

\section{Edita:}

(C) Ministerio para la Transición Ecológica y el Reto Demográfico Agencia Estatal de Meteorología

Delegación Territorial en Cataluña Barcelona, 2021

Catálogo de Publicaciones de la Administración General del Estado: https://cpage.mpr.gob.es

NIPO: 666-20-027-X

https://doi.org/10.31978/666-20-027-X

Agencia Estatal de Meteorología (AEMET)

C/ Leonardo Prieto Castro, 8

28040 Madrid

http://www.aemet.es/

@Aemet_Esp 


\section{ÍNDICE}

1. Introducción 4

2. Contexto geográfico 6

3. Observaciones 8

4. Impactos 14

5. Entorno sinóptico y mesoescalar 16

6. Análisis de las estructuras convectivas 23

7. Comportamiento de los modelos numéricos operativos 31

8. Conclusiones 35

9. Agradecimientos 36

10. Bibliografía $\quad 37$ 


\section{Introducción}

Durante los días 22 y 23 de octubre de 2019 tuvo lugar en Cataluña un episodio de precipitaciones muy intensas, incluso torrenciales, con tormentas. Las inundaciones repentinas producidas afectaron a varias zonas, especialmente en la provincia de Tarragona, donde el río Francolí se desbordó, así como del sur de la provincia de Lleida y el nordeste de Cataluña en la última parte del evento. Como resultado de este episodio hubo 4 muertos, y dos personas aún desaparecidas, así como otros impactos catastróficos.

El 22 de octubre la situación meteorológica estaba regida por la presencia de una dana (depresión aislada en niveles altos) centrada sobre el suroeste de la península ibérica, que inducía un fuerte forzamiento dinámico sobre el norte y el nordeste de España. En niveles bajos había una región de bajas presiones que abarcaba desde el norte de África hasta el sur de la Península, con dos centros: uno sobre Argelia, y el otro, en el entorno de las islas Baleares. Asociado a esta última baja, un frente cruzaba el Mediterráneo occidental de sur a norte, situándose su sector cálido sobre el nordeste de la Península. Este paso frontal indujo la entrada de un flujo de aire mediterráneo muy húmedo e inestable en Cataluña.

La combinación del forzamiento dinámico, las bajas presiones en superficie, el paso frontal cálido y el flujo húmedo e inestable dio lugar a convección organizada, con fuertes aguaceros y tormentas durante la tarde del día 22 y las primeras horas del día 23. Estas condiciones dinámicas y termodinámicas, combinadas con otros factores mesoescalares, como la presencia de una línea de convergencias en niveles bajos (superficie, $1000 \mathrm{hPa}$ ) favorecieron la formación de una línea estacionaria de células convectivas que fueron penetrando sucesivamente en la provincia de Tarragona y llegando hasta el sur de la de Lleida durante varias horas, dando lugar al llamado "efecto de tren convectivo" (Doswell et al.,1996) y causando precipitaciones muy intensas y persistentes que desbordaron el río Francolí. También se produjeron más tarde otros fenómenos severos (lluvias intensas, tornados, reventones...), al desplazarse la zona inestable hacia el nordeste de Cataluña en la noche del 22 y la madrugada del 23.

Es sabido que los sistemas tormentosos cuasi-estacionarios o con muy lento movimiento producen frecuentemente precipitación intensa y copiosa y flash-floods (inundaciones repentinas). Estos sistemas convectivos se componen de muchas tormentas individuales en diferentes fases de sus ciclos de vida. Las tormentas individuales frecuentemente tienen trayectorias que las llevan por la misma región, produciendo lluvias "pulsantes" que rápidamente causan el desbordamiento de ríos y arroyos (Chappell, 1986).

Las inundaciones constituyen el principal riesgo natural en el mundo, siendo su impacto mayor que el de ningún otro desastre natural en España. Aproximadamente un $12 \%$ de las muertes por desastres naturales están causadas por inundaciones. Se ha observado una tendencia de aumento del valor promedio de una inundación (de carácter extraordinario) por década en Cataluña probablemente debida sobre todo a cambios en la densidad de población, en los usos del suelo y en la cubierta vegetal, más que a un aumento de la precipitación (Llasat et al., 2014). 
La mayor parte de las inundaciones en la zona mediterránea occidental son debidas a la entrada de aire cálido y húmedo marítimo en niveles bajos, principalmente durante el verano y el otoño. La región mediterránea es proclive a las inundaciones repentinas, especialmente en el noroeste (Jansà et al., 2014), donde las cadenas montañosas del litoral y prelitoral favorecen, en general, la precipitación de intensidad fuerte y también la lluvia torrencial concentrada en pequeñas cuencas. La concentración en poco tiempo y las extraordinarias escorrentías que se desarrollan pueden hacer que una inundación sea catastrófica (Llasat et al., 2016). Las inundaciones de tipo catastrófico pueden vincularse a una precipitación máxima superior a $200 \mathrm{~mm} / 24 \mathrm{~h}$, incluso las más destructivas poseen valores de precipitación acumulada de $200 \mathrm{~mm}$ en menos de 3 horas, estando asociadas a sistemas multi-celulares (usualmente "trenes convectivos") y sistemas convectivos de mesoscala (SCM). Estas inundaciones catastróficas producen daños severos o la completa destrucción de infraestructuras cercanas al río o lejos del cauce principal: puentes, diques, muros, casas, sistemas de drenaje, cultivos, obras de drenaje de carreteras... (Llasat et al., 2014; Barrera et al., 2006).

En torno al 10,5\% de los flash-floods son de tipo catastrófico en Cataluña (Llasat et al., 2014). Se ha observado que los meses en que se producen más inundaciones catastróficas son los de octubre $(27 \%)$ y noviembre $(27 \%)$, detectándose una tendencia de ligero aumento. Además, las inundaciones catastróficas están en su mayoría conectadas, aunque no exclusivamente, con patrones sinópticos ciclónicos (Gilabert et al., 2017; Jansà et al., 2014; Llasat et al., 2013).

En este estudio se han analizado en profundidad las causas meteorológicas que condujeron a los importantes impactos producidos, a través de la exploración de las imágenes de teledetección (satélite, radar, rayos), las salidas de diferentes modelos numéricos y las observaciones convencionales. La fenomenología y los impactos también han sido estudiados a través del análisis de la información en los medios de comunicación y redes sociales. Este caso de estudio es un buen ejemplo de las capacidades de las herramientas operativas y de la especial importancia de la labor de vigilancia, el nowcasting y la predicción a muy corto plazo a la hora de prevenir daños mayores.

Aunque se describirá la situación meteorológica que afectó a toda Cataluña se analizará con mayor detalle el episodio que afectó a la cuenca del río Francolí, en la provincia de Tarragona. 


\section{Contexto geográfico}

En la vertiente mediterránea de la península ibérica los ríos acostumbran a ser de corto recorrido y, como se alimentan fundamentalmente de las lluvias estacionales, su caudal es relativamente pequeño a excepción de cuando se producen las avenidas pluviales. El río Francolí (fig. 1) recorre $85 \mathrm{~km}$ desde su nacimiento en las montañas de Prades, en la cordillera Prelitoral Catalana, hasta su desembocadura en la ciudad de Tarragona. Su cuenca es de $838 \mathrm{~km}^{2}$, con una gran cantidad de pequeños afluentes intermitentes que le pueden aportar un mayor caudal. Su nacimiento se ha establecido en el pueblo de l'Espluga de Francolí, en la Font Major, que se encuentra en su casco urbano. Es un río peculiar, que no cumple el orden normalmente establecido, ya que su nacimiento oficial se encuentra en el curso medio. De esta forma, la cuenca alta del río hace referencia a la cabecera de sus afluentes (Brugent, Glorieta, Anguera, Riera de la Selva). Desemboca en la ciudad de Tarragona, canalizado y con un aspecto de un torrente de desagüe seco durante la mayor parte del año.

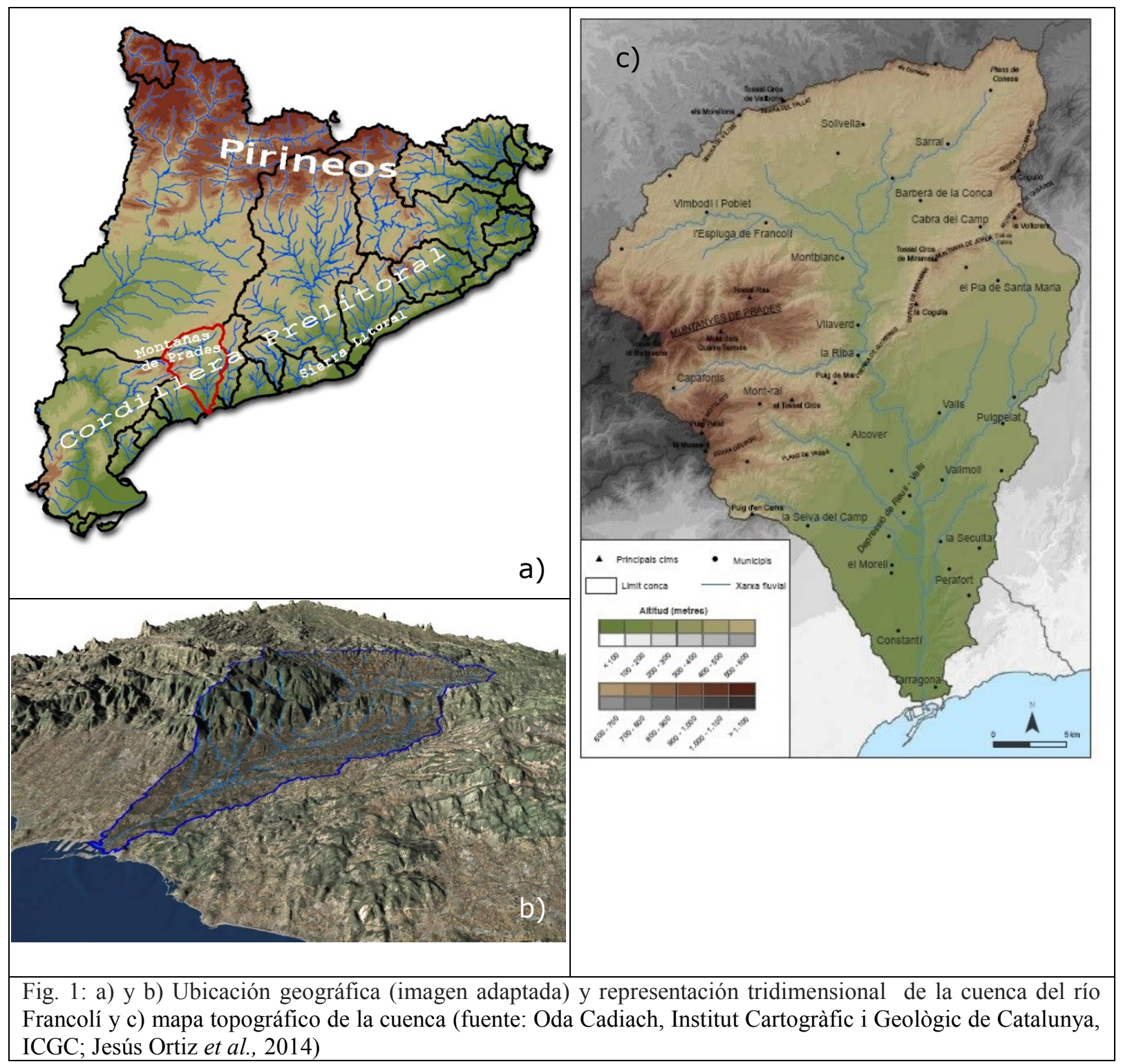


La cordillera Prelitoral Catalana se extiende con orientación paralela a la costa (nordeste-sudoeste) desde el macizo de Les Guilleries, en el límite de las provincias de Barcelona y Girona, hasta el macizo de Els Ports (Ports de Tortosa-Beseit), en el extremo sudoeste de la provincia de Tarragona. Esta cordillera, junto con la cordillera Litoral, paralela y de altura menor, juega un papel meteorológico muy relevante al interceptar los flujos húmedos de componente este (marítimos), forzar su ascenso y dar lugar, si las condiciones son favorables, a precipitaciones copiosas e intensas. 


\section{Observaciones}

Durante el día 22 y las primeras horas del 23 de octubre se produjeron precipitaciones muy abundantes, de intensidad fuerte, muy fuerte e incluso puntualmente torrencial, en muchas comarcas de Cataluña, especialmente en las provincias de Tarragona y Girona y en el sur de la Lleida. En algunos lugares fueron también persistentes. Estas precipitaciones estuvieron acompañadas de numerosísimas descargas eléctricas en toda Cataluña (ver punto 6). Asimismo, se registraron rachas de viento fuertes o muy fuertes de origen convectivo en diversos puntos del territorio.

\section{2 de octubre}

A lo largo de este día las precipitaciones más abundantes se produjeron en las provincias de Lleida y Tarragona. En Lleida, las comarcas más afectadas fueron las más meridionales: Les Garrigues y el Pla d'Urgell. En Tarragona, fueron aquellas afectadas por la línea de tormentas (tren convectivo), en concreto: el Priorat, el Baix Camp y la Conca de Barberà. En ambas provincias hubo muchos registros que superaron los 150 $\mathrm{mm} / 24 \mathrm{~h}$, y varios quedaron por encima de los $200 \mathrm{~mm} / 24 \mathrm{~h}$. A su vez, hubo otros máximos secundarios en varias comarcas de la provincia de Barcelona (Bages, Maresme, Vallès Occidental y Vallès Oriental) que superaron los $100 \mathrm{~mm} / 24$ h, así como en Girona (Alt Empordà, Baix Empordà y Ripollès) (fig. 2).
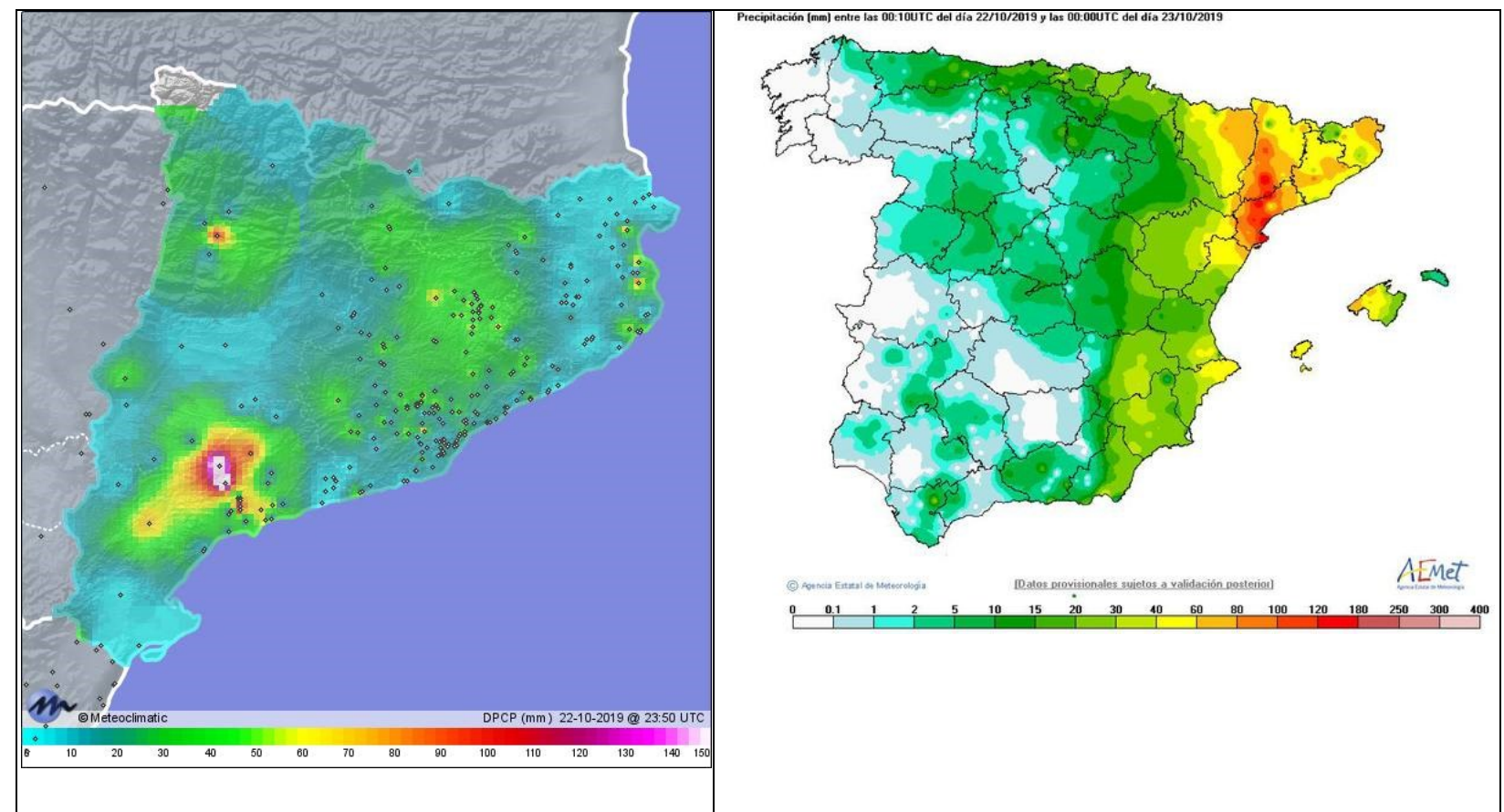

Fig. 2: Registros de precipitación acumulada en 24 h para el día 22 de octubre de la red de estaciones automáticas de Meteoclimatic (izda.) y AEMET (dcha.).

A continuación, se muestran los registros obtenidos en diversas redes para las distintas provincias durante el día 22: 
$\circ$ Lleida:

- El Vilosell (Les Garrigues): 250,2 mm (AEMET)

- La Pobla de Cérvoles (Les Garrigues): 234,6 mm (AEMET)

- Cervià de les Garrigues (Les Garrigues): 162,4 mm (Meteoclimatic)

- Borges Blanques (Les Garrigues): 158,7 mm (SMC)

- Castellnou de Seana (Pla d'Urgell): 158,4 mm (SMC)

- Mollerussa (Pla d'Urgell): 150,7 mm (SMC), 149,2 mm (AEMET)

- Tarragona:

- Prades (Baix Camp): 287,4 mm (SMC)

- La Mussara (Baix Camp): 233,2 mm (Meteoclimatic)

- Ulldemolins (Priorat): 212,8 mm (SMC)

- Riudoms Nord (Baix Camp): 201,4 mm (Meteoclimatic)

- Vinyols i els Arcs (Baix Camp): 197,4 mm (SMC)

- Prades (Baix Camp): 185 mm (Meteoclimatic)

- Cornudella de Montsant (Priorat): $180 \mathrm{~mm}$ (Meteoclimatic)

- Cambrils (Baix Camp): 178,2 mm (Meteoclimatic)

- Poboleda (Priorat): 171,6 mm (AEMET)

- Pantà de Siurana (Priorat): 175,9 mm (SMC)

- Tivissa (Baix Camp): 162,2 mm (SMC)

- Falset (Priorat): 159,7 (SMC)

- L'Espluga de Francolí (Conca de Barberà): 156,7 mm (SMC)

- Els Guiamets (Priorat): 152,6 mm (AEMET)

Por otra parte, también se recogieron cantidades considerables en la zona del Delta del Ebro, en las comarcas del Montsià y el Baix Ebre, con varias estaciones que superaron los 100 mm/24 h (p.e. Els Alfacs: 144,8 mm)

○ Barcelona:

- Rellinars (Vallès Occidental): 125,5 mm (SMC)

- Sant Salvador de Guardiola (Bages): 112, 6 mm (SMC)

- Puig Sesolles (Vallès Oriental): 115,4 mm (SMC)

- Matadepera (Vallès Occidental): 113,5 mm (Meteoclimatic)

- Terrassa (Vallès Occidental): 109,6 mm (Meteoclimatic)

- Sant Llorenç Savall (Vallès Occidental): 109,9 mm (SMC)

- El Pont de Vilomara (Bages): 107,5 mm (SMC)

- Arenys de Mar (Maresme): 105,6 mm (Meteoclimatic)

○ Girona:

- Ulldeter (Ripollès): 126,4 mm (SMC)

- Torroella de Fluvià (Alt Empordà): 103,5 mm (SMC)

- Torroella de Montgrí (Baix Empordà): 102,3 mm (SMC) 


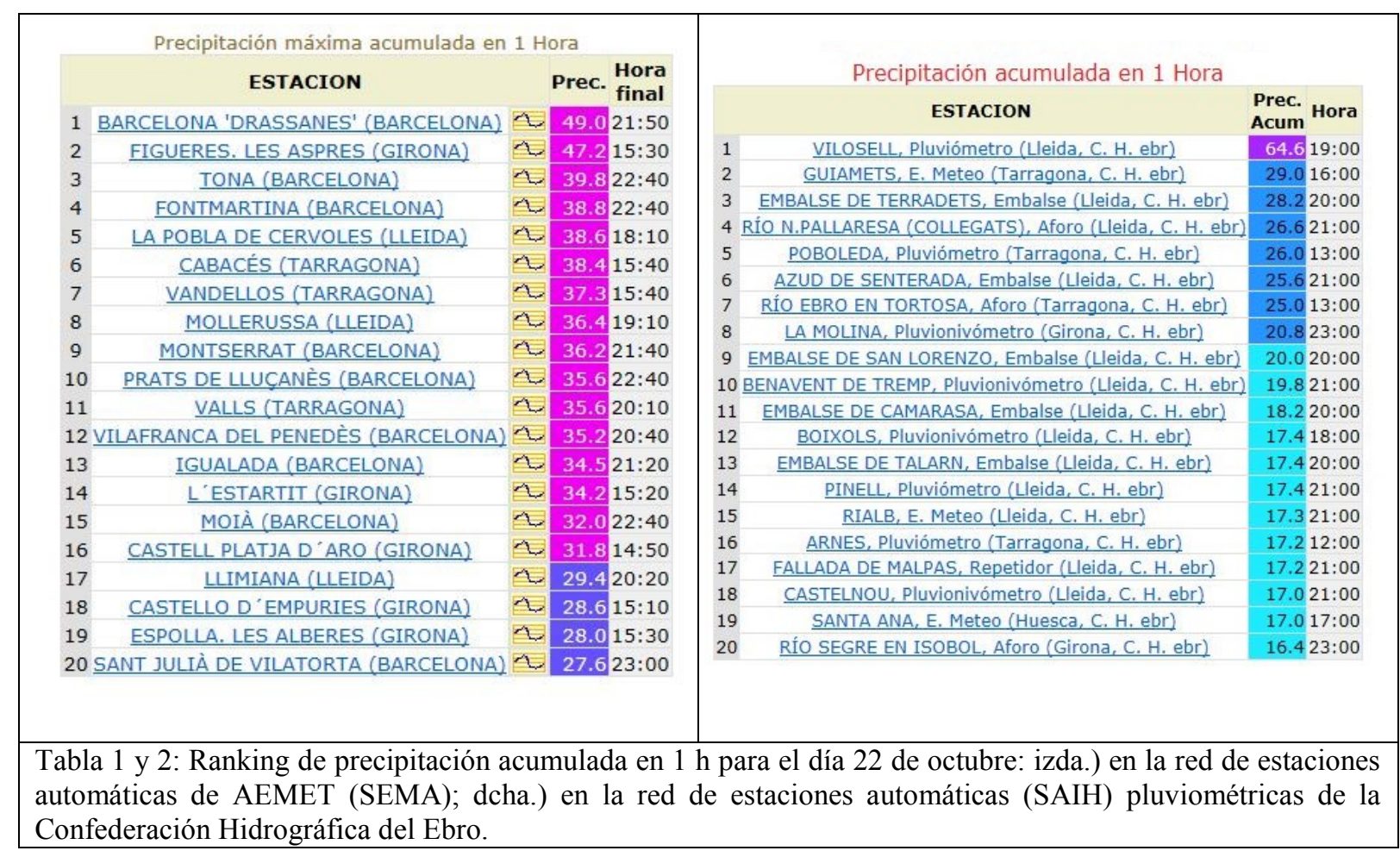

En cuanto a las intensidades horarias (AEMET, tabla 1; CHE, tabla 2), cabe destacar el dato de 64,6 mm caídos en una hora (intensidad torrencial) que se alcanzó en el Vilosell (Les Garrigues, Lleida), seguido de Barcelona con 49,0 mm caídos en una hora (intensidad muy fuerte) y Figueres (Alt Empordà, Girona) con 47,2 mm (muy fuerte). Muchas estaciones de todas las provincias superaron los $20 \mathrm{~mm}$ en una hora (intensidad fuerte). Sin embargo, sí que se alcanzó intensidad torrencial $(>60 \mathrm{~mm} / \mathrm{h})$ en muchos puntos en periodos de tiempo menores de una hora, con intensidades equivalentes de: $127,2 \mathrm{~mm} / \mathrm{h}$ en Fontmartina - Barcelona (AEMET, 21,2 mm/10 min); 109,2 mm/h en Barcelona Drassanes (AEMET, 18,2 mm/10 min); 92,4 mm/h en Castelló d'Empúries Girona (AEMET, 15,4 mm/10 min), etc. Principalmente, las intensidades máximas se registraron en las provincias de Barcelona y Girona, aunque también hubo intensidades torrenciales (equivalentes) de menor magnitud en Tarragona, como, por ejemplo: 96,2 $\mathrm{mm} / \mathrm{h}$ en Mont-roig del Camp - Tarragona (SMC) con 48,1 mm en $30 \mathrm{~min}$, o 88,4 mm/h en Prades (SMC) con 44,2 mm en 30 min.

En cuanto a las rachas de viento máximas (Tabla 3), se alcanzaron valores superiores a los $100 \mathrm{~km} / \mathrm{h}$ en el Pirineo. Las máximas fuera de la zona pirenaica estuvieron asociadas a las estructuras convectivas, registrándose en zonas del Pla de Lleida, Tarragona y puntos del litoral barcelonés durante la tarde (entre 70 y $90 \mathrm{~km} / \mathrm{h}$ ), y más tarde, al final del día, a medida que se desplazaron las tormentas hacia el nordeste, en el Maresme y en el prelitoral de Barcelona, con rachas en algún caso superiores a $90 \mathrm{~km} / \mathrm{h}$ (según datos de diversas redes de estaciones automáticas) (fig. 3) 

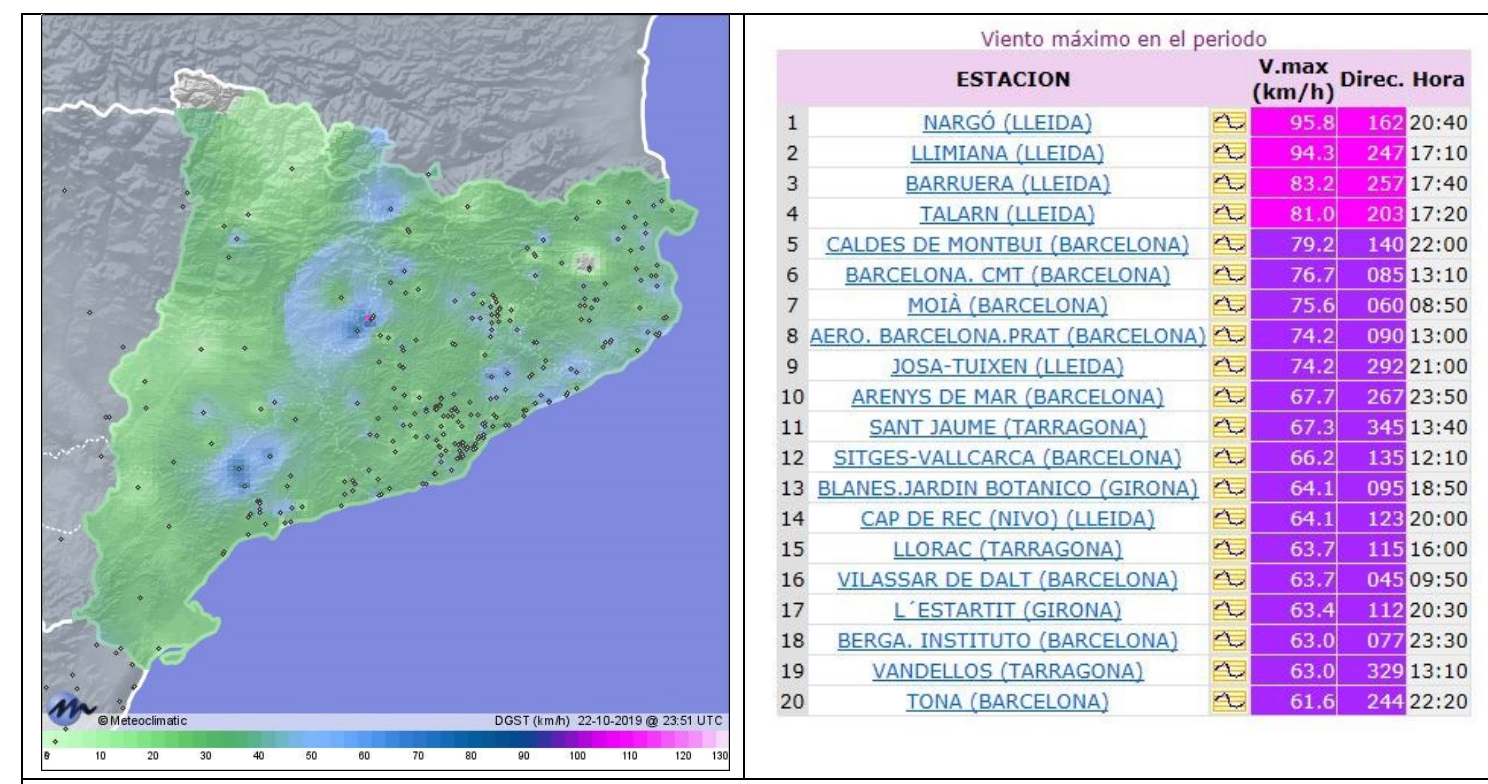

Fig. 3: Mapa de rachas máximas de viento durante el día 22 en la red de estaciones automáticas de Meteoclimatic; Tabla 3: Ranking de rachas máximas de viento del día 22 en la red de estaciones automáticas de AEMET en Cataluña.

\section{3 de octubre}

Durante la madrugada de este día se registraron valores máximos de precipitación principalmente en las provincias de Girona y Barcelona. Las comarcas más afectadas fueron el Alt y el Baix Empordà (Girona) y el Vallès Occidental, el Oriental y el Maresme (Barcelona) (fig. 4). Se alcanzaron intensidades horarias aún mayores que el día anterior, principalmente en el Alt Empordà (Girona) y en la comarca del Vallès Oriental, en el macizo del Montseny (Barcelona).

\section{○ Girona}

- Les Olives (Baix Empordà): 117,6 mm (Meteoclimatic)

- Sant Miquel de Fluvià (Alt Empordà): 116,8 mm (Meteoclimatic)

- Castelló d'Empúries (Alt Empordà): 110 mm (SMC), 108,2 mm (AEMET)

- Sant Climent Sescebes (Alt Empordà): 107,2 mm (Meteoclimatic)

- Espolla (Alt Empordà): 107 mm (AEMET), 106,3 mm (SMC)

- Torroella de Fluvià (Alt Empordà): 105,1 mm (SMC)

- Llançà (Alt Empordà): 95,8 mm (Meteoclimatic)

- Verges Ponent (Baix Empordà): 94,6 mm (Meteoclimatic)

\section{○ Barcelona}

- Palau-Solità i Plegamans (Vallès Occidental): 100,2 mm (Meteoclimatic)

- Arenys de Munt (Maresme): $87 \mathrm{~mm}$ (Meteoclimatic)

- Rubí (Vallès Occidental): 83 mm (Meteoclimatic) 


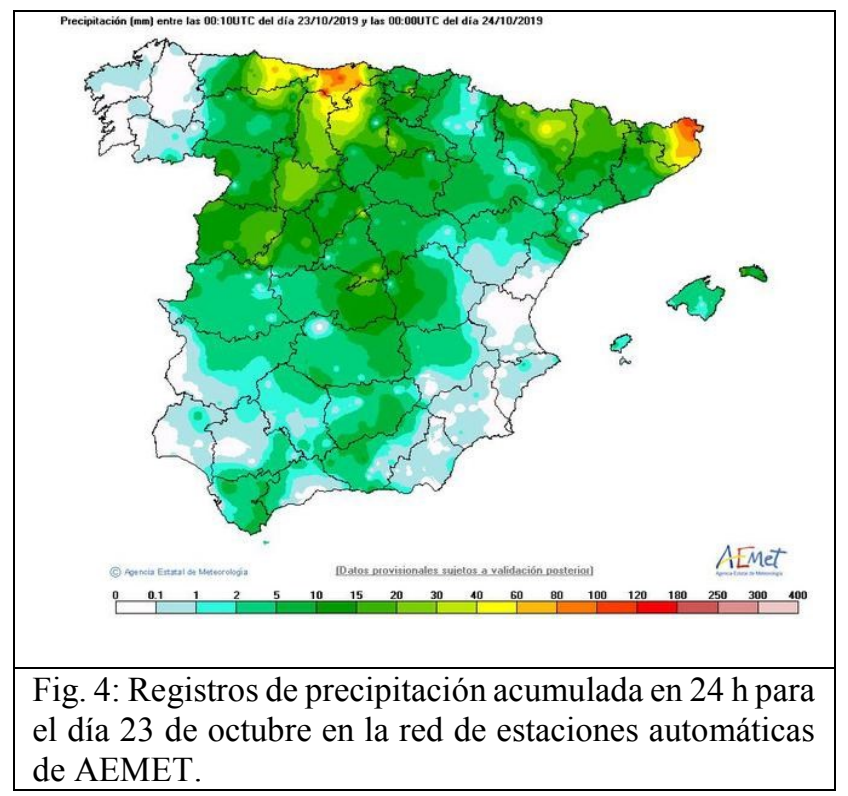

Respecto a las intensidades horarias son relevantes los registros de intensidad torrencial ( $>60 \mathrm{~mm} / 1 \mathrm{~h})$ en varios puntos del Alt Empordà en Girona: Figueres, Espolla y Castelló d'Empúries, recogiéndose en esta última 77,8 $\mathrm{mm}$ en una hora (tabla 4). Igualmente, al día anterior, sí que se alcanzaron intensidades torrenciales equivalentes en muchos puntos de las provincias de Barcelona y Girona, en periodos de tiempo menores de una hora, llegándose a valores incluso superiores al día previo. Las intensidades equivalentes fueron de 157,2 $\mathrm{mm} / \mathrm{h}$ en Castellò d'Empúries, Girona (AEMET, 26,2 $\mathrm{mm} / 10 \mathrm{~min}$ ), 141,6 mm/h en Sant Pau de Segúries, Girona (AEMET, 23,6 mm/10 min), $128,4 \mathrm{~mm} / \mathrm{h}$ en Espolla- Les Alberes, Girona (AEMET, 21,4 mm/10 min), $127 \mathrm{~mm} / \mathrm{h}$ en Fontmartina, Barcelona (AEMET, 21,2 mm/10 min), etc.

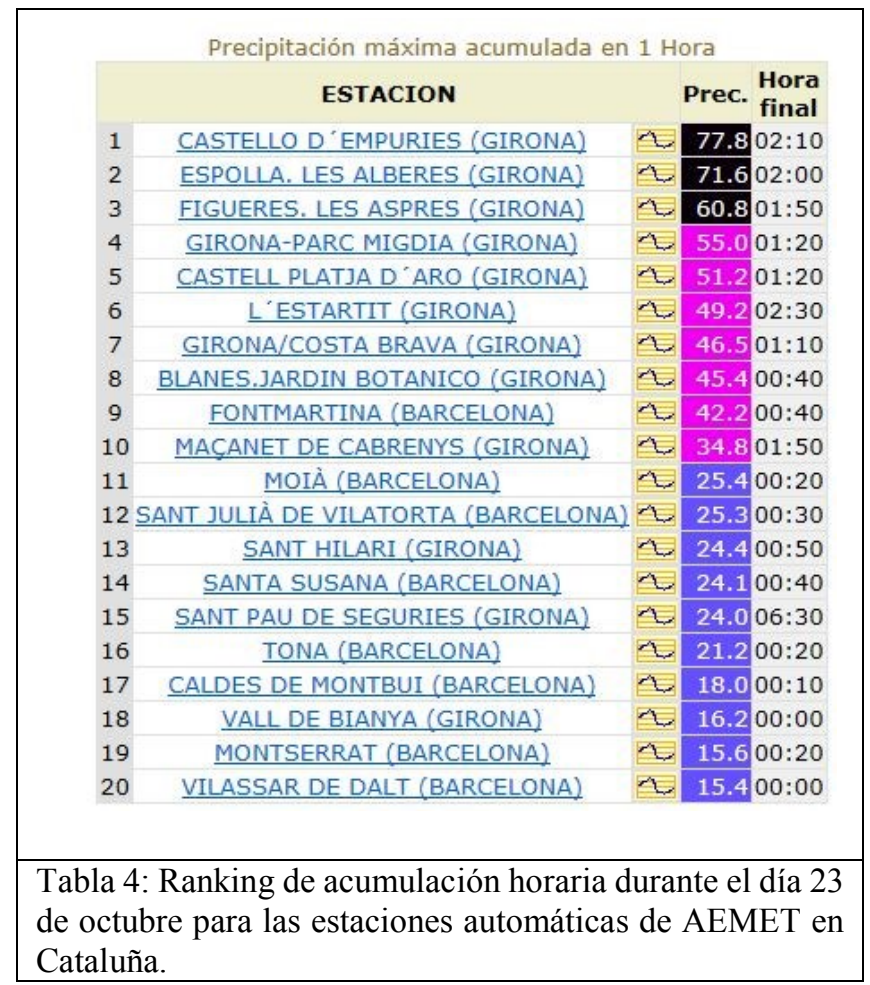


Las rachas máximas de viento del día 23, asociadas a las tormentas de la madrugada, también fueron fuertes o muy fuertes. Principalmente se dieron en las comarcas del Maresme y el Vallès Oriental (Barcelona) y en el Alt Empordà (Girona), probablemente vinculadas algunas de ellas a los fenómenos que se analizan más adelante (probable tornado y varios microrreventones) (tabla 5).

\section{○ Barcelona}

- Calella (Maresme): $134 \mathrm{~km} / \mathrm{h}$ (Meteoclimatic)

- Puig Sesolles (Vallès Oriental): 108 km/h (SMC)

- Arenys de Munt (Maresme): $94 \mathrm{~km} / \mathrm{h}$ (Meteoclimatic)

- Arenys de Mar (Maresme): $85 \mathrm{~km} / \mathrm{h}$ (Meteoclimatic)

\section{○ Girona}

- Figueres (Alt Empordà): 92,9 km/h (AEMET)

- Portbou (Alt Empordà): 87,8 km/h (SMC)

- Espolla, Les Alberes (Alt Empordà): 79,6 (AEMET)

- Darnius (Alt Empordà): 79 km/h (Meteoclimatic)

- Verges Ponent (Alt Empordà): 76 km/h (Meteoclimatic)

\begin{tabular}{|c|c|c|c|c|}
\hline \multicolumn{5}{|c|}{ Viento máximo en el periodo } \\
\hline \multicolumn{3}{|c|}{ ESTACION } & $\begin{array}{l}\text { V.max } \\
(\mathbf{k m} / \mathbf{h})\end{array}$ & Direc. Hora \\
\hline 1 & FIGUERES. LES ASPRES (GIRONA) & 2 & 92.9 & $21001: 00$ \\
\hline 2 & ESPOLLA. LES ALBERES (GIRONA) & 2 & 79.6 & $23201: 20$ \\
\hline 3 & SANT HILARI (GIRONA) & L & 70.2 & $15500: 10$ \\
\hline 4 & VALL DE BIANYA (GIRONA) & a & 65.9 & $06200: 30$ \\
\hline 5 & MAÇANET DE CABRENYS (GIRONA) & D & 63.7 & $21501: 10$ \\
\hline 6 & L'ESTARTIT (GIRONA) & 2 & 62.3 & $10200: 40$ \\
\hline 7 & SITGES-VALLCARCA (BARCELONA) & 2 & 60.1 & $32501: 00$ \\
\hline 8 & CASTELLO D'EMPURIES (GIRONA) & 2 & 58.0 & $07000: 50$ \\
\hline 9 & GIRONA/COSTA BRAVA (GIRONA) & 2 & 53.6 & $22000: 10$ \\
\hline 10 & OS DE BALAGUER (LLEIDA) & 2 & 53.6 & $03501: 50$ \\
\hline 11 & CALDES DE MONTBUI (BARCELONA) & 2 & 49.0 & $31700: 10$ \\
\hline 12 & MOLLERUSSA (LLEIDA) & 2 & 46.8 & $05501: 40$ \\
\hline 13 & BOSSOST-CENTRAL (LLEIDA) & 2 & 46.4 & $24713: 10$ \\
\hline 14 & CAP DE REC (NIVO) (LLEIDA) & Z & 46.4 & $10904: 20$ \\
\hline 15 & CASTELL PLATJA D ARO (GIRONA) & 2 & 45.7 & $09700: 10$ \\
\hline 16 & VILASSAR DE DALT (BARCELONA) & 2 & 45.4 & $34001: 10$ \\
\hline 17 & GIRONA-PARC MIGDIA (GIRONA) & 2 & 45.0 & $17700: 30$ \\
\hline 18 & LLORAC (TARRAGONA) & 1 & 44.3 & $00501: 40$ \\
\hline 19 & AERO. BARCELONA.PRAT (BARCELONA) & 2 & 42.5 & $24021: 10$ \\
\hline 20 & MARTINET (LLEIDA) & D & 42.5 & $07204: 20$ \\
\hline $\mathrm{Ca}$ & para las estaciones au & & de & $\begin{array}{l}1 \text { dia } 23 \\
\text { AEMET }\end{array}$ \\
\hline
\end{tabular}




\section{Impactos}

El paso de la dana durante el día 22 y primeras horas del 23 provocó importantes daños humanos y materiales. Las comarcas más afectadas fueron las de Tarragona y sur de Lleida: la Conca de Barberà, Les Garrigues (Lleida), el Baix Camp, el Priorat y la Ribera de l'Ebre. A su vez, los municipios más afectados a causa de las riadas fueron: Salou, Cambrils, Espluga de Francolí, Reus, Mont-Roig del Camp, Tarragona y Montblanc. La respuesta hidrológica fue severa en los ríos Francolí (Martín Vide et al., 2020) y Siurana, cuyo embalse de cabecera incrementó en un $30 \%$ el volumen de agua almacenada, y también en rieras de la Conca de Barberà, el Baix Camp y el Tarragonès. El hecho más grave fue la riada del río Francolí, que multiplicó por mil su caudal (en el sensor de nivel de Tarragona el caudal pasó, sólo en 15 minutos, de 50 a $1238 \mathrm{~m}^{3} / \mathrm{s}$ : ACA, 2019) y arrasó el municipio de L'Espluga de Francolí (fig. 5), llevándose por delante dos puentes, una bodega y un restaurante, así como el parque fluvial con una zona de juegos infantiles, un almacén de la brigada municipal y los voluntarios forestales, y el aparcamiento de autocaravanas, algunas de las cuales se llevó por delante el agua. Hubo 215 afectaciones, entre ellas 102 huertos, 16 viviendas, 5 establecimientos comerciales, 5 almacenes y 16 vehículos que quedaron destrozados. Se calcula que los daños municipales ascendieron a 1,6 millones de euros. La riada, a su paso por el camping de Vilaverd (población colindante con L'Espluga), arrastró un bungalow con dos personas dentro (encontradas sin vida posteriormente). También en Montblanc hubo desperfectos y daños serveros: bajos inundados, coches atrapados y un puente medieval sobre el Francolí arrancado (Pont Vell, fig. 5.d.).

Asimismo, el barranco Barenys se desbordó a su paso por Salou. En Cambrils, 50 niños fueron desalojados de una casa de colonias. La riera de Alforja se desbordó, inundando calles y derruyendo parcialmente otro puente. Al menos 20 centros escolares fueron cerrados (531 alumnos sin clase). En Lleida, el servicio de muchos autobuses escolares fue cortado.

En total, el balance de víctimas mortales fue de 4 personas (una fue arrastrada en una riera de Arenys de Munt - Barcelona, y el resto en la cuenca del Francolí) y dos desaparecidos (Tarragona). Se produjo el descarrilamiento de un tren entre Vinaixa y Vimbodí i Poblet (Tarragona), quedando el maquinista herido.

También hubo 3 heridos en un camping de Gualba (Girona) arrasado como consecuencia de un probable tornado en la madrugada del día 23 (fig. 6). Este tornado también afectó al municipio vecino de Riells i Viabrea. Los daños fueron cuantiosos y de diferentes tipos: arbolado, infraestructuras (incluyendo alguna torre eléctrica) y más de 100 mobile-homes, caravanas y vehículos en la zona del camping Aqua Alba de Gualba. También se produjeron muy probablemente al menos dos microrreventones en Ventalló y Sant Martí de Llémena (Girona) durante la madrugada del día 23.

Hubo al menos 5 rescates de personas atrapadas en sus coches por parte de emergencias.

Al menos 60 carreteras fueron cortadas por inundación, la mayor parte locales (p.e.: AP7 entre Vila-seca y Cambrils, la AP-2 entre Albatàrrec y Tarrés, la C-233 en Castelldans, la C-252 en Vilabertran y la C-32 en Esplugues, la GIV-6211 en Figueres; 
la GIV-6301, en Armentera; la N-240 en Borges Blanques, y la T-312 en Cambrils). También, varias líneas de ferrocarril quedaron sin servicio (53 tramos cortados el 23 a las 15 h). Más de 30.000 domicilios se quedaron sin luz y fueron comunicadas 3.125 incidencias al 112 (hasta el 23 a las 13:00 h). Al menos dos vuelos fueron desviados del aeropuerto de Reus a El Prat-Josep Tarradellas de Barcelona.

En l'Estartit, el día 23 se registraron olas de al menos 4 m (la altura mínima fue de 3 y la máxima de $5 \mathrm{~m}$ ).
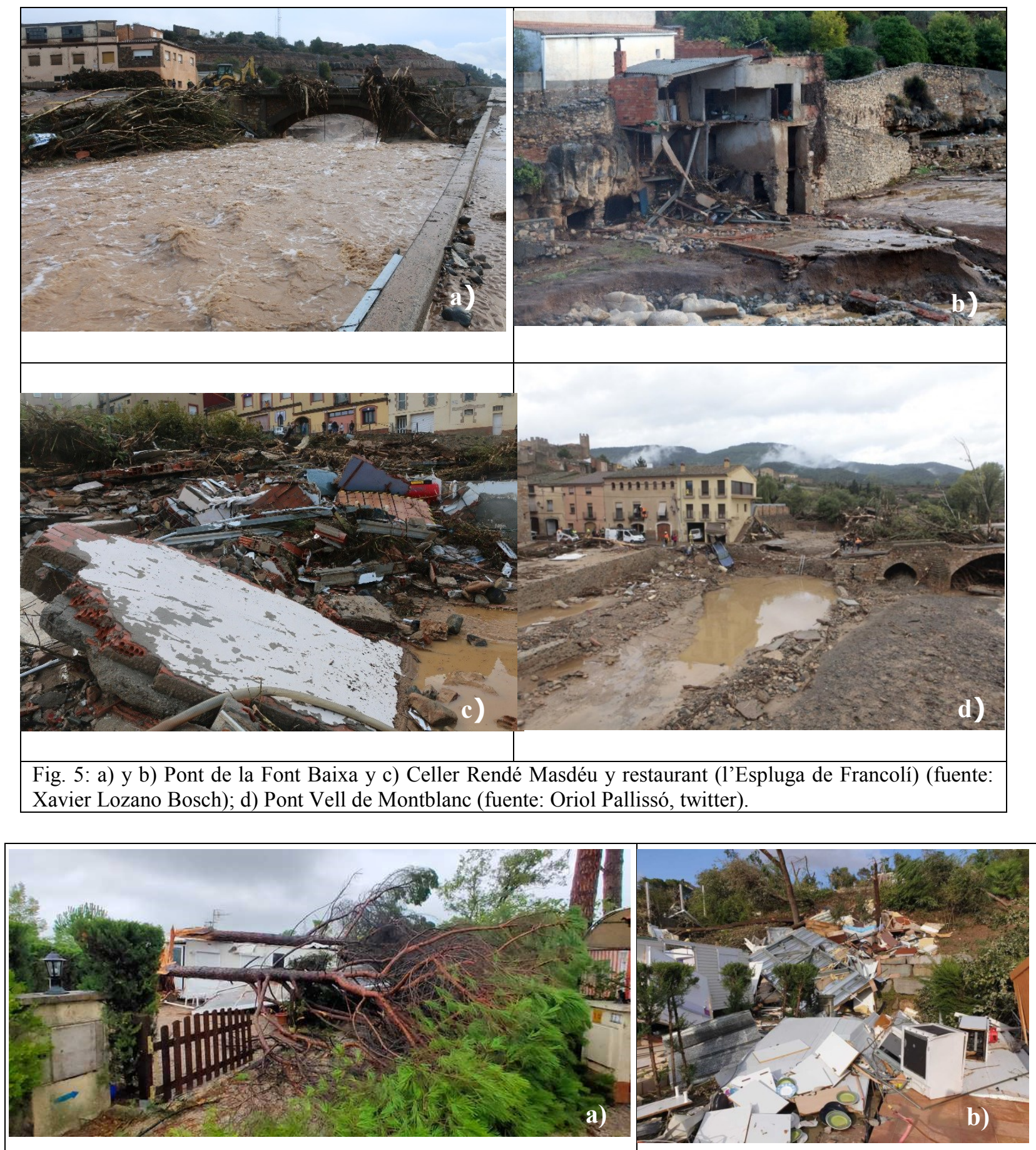

Fig. 6: a) y b) Destrozos provocados por el tornado que arrasó el camping Aqua Alba en Gualba (Barcelona) (Fuente: Club Caravaning Aqua Alba). 


\section{Entorno sinóptico y mesoescalar}

La situación sinóptica a lo largo de los días 22 y 23 de octubre en niveles mediosaltos $(500 \mathrm{hPa})$ estuvo regida por la presencia de una dana que se trasladó entre las 12 UTC del día 22 y las 12 UTC del día 23 del oeste al este de la península ibérica, con su centro pasando por Andalucía y dejando a Cataluña bajo la parte delantera de dicha dana durante el día 22, favoreciendo las ascendencias de aire húmedo. En superficie, a lo largo del día 22, dominaba un anticiclón sobre el área de las islas Azores, con valores de hasta $1027 \mathrm{hPa}$ en su centro a las 00 UTC, que fue debilitándose a lo largo del día, y una zona de bajas presiones se situaba entre el norte de África y el Mediterráneo occidental con un valor mínimo de $1004 \mathrm{hPa}$ a las $00 \mathrm{UTC}$ del día 23 sobre el mar Balear. Entre las 06 y las 18 UTC del día 22 un frente cálido mediterráneo cruzó Cataluña de este a oeste. Esta situación meteorológica fue muy favorable a las precipitaciones fuertes, persistentes y con tormenta.

A las 00 UTC del día 22 la amplia dana (presente en 500 y $300 \mathrm{hPa}$ ) se situaba sobre el oeste de la Península, centrada sobre la costa central de Portugal (Fig. 7). Tenía un núcleo frío de $-24{ }^{\circ} \mathrm{C}$ en $500 \mathrm{hPa}$ (fig. 7), y dos chorros, trasero (130 kt del N) y delantero (90 kt del S) descompensados, lo que provocó su enroscamiento. El chorro delantero estaba situado en la zona de difluencia de la rama ascendente de la dana en un área, por lo tanto, de fuerte forzamiento dinámico, favorable al desarrollo de convección profunda sobre el nordeste peninsular desde las 12 UTC del día 22 hasta las 06 UTC del 23. En 300 $\mathrm{hPa}$, el flujo en la costa mediterránea de la península era inicialmente del SE, pero fue virando al E.
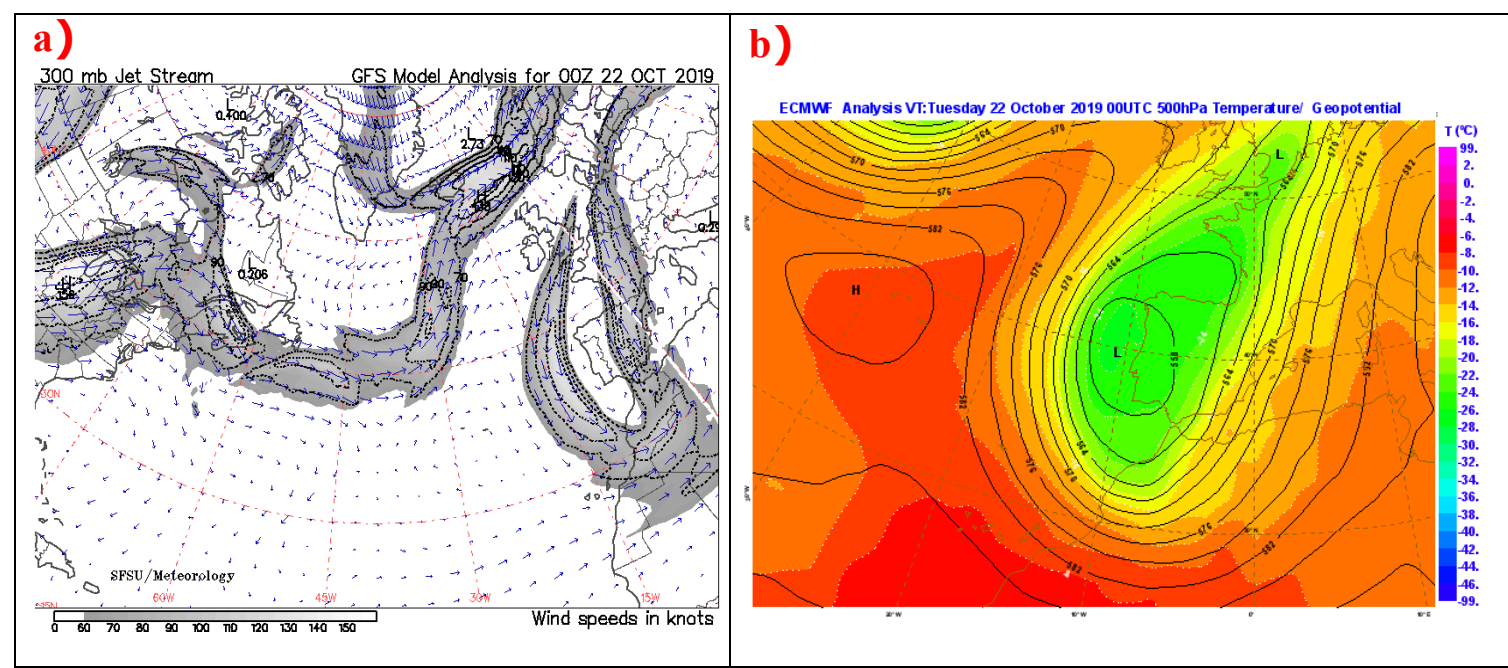

Fig. 7: a) Análisis del modelo GFS del campo de velocidad del viento en $300 \mathrm{hPa}$ (Jet streaks) a las 00 UTC del día 22; b) Análisis del campo de temperatura (coloreado) y geopotencial (isolíneas) en $500 \mathrm{hPa}$ del modelo HRES-IFS para las 00 UTC del día 22.

La dana se fue desplazando hacia el sur-sureste, situándose a las 12 UTC del día 22 sobre el golfo de Cádiz. A las 00 UTC del día 23, la dana abarcaba Andalucía (con núcleo frío de $-22{ }^{\circ} \mathrm{C}$ en $\left.500 \mathrm{hPa}\right)$, con un potente chorro al sur $(120 \mathrm{kt})$ y otro al norte de componente este $(90 \mathrm{kt})$. A las 12 UTC del día 23, la dana, con varios vórtices embebidos, abarcaba ya prácticamente toda la Península y el Mediterráneo occidental. La zona 
difluente se alejó por el nordeste de Cataluña, disminuyendo el forzamiento dinámico. El flujo en $500 \mathrm{hPa}$ fue inicialmente del S y luego del SE sobre el nordeste peninsular y Baleares (ligeramente desfasado con el flujo del E en $300 \mathrm{hPa}$, debido a diferencias en la posición de la dana entre los dos niveles). Entre las 12 UTC del día 22 y las 12 UTC del 23 la temperatura en $500 \mathrm{hPa}$ (aproximadamente $5500 \mathrm{~m}$ de altitud) sobre el nordeste peninsular bajó desde $-15^{\circ} \mathrm{C}$ hasta $-20^{\circ} \mathrm{C}$.

En superficie, durante el día 22, había un anticiclón sobre el Atlántico Norte, y las altas presiones dominaban prácticamente toda Europa, incluyendo el tercio norte peninsular (fig. 8). En el norte de África dominaban las bajas presiones en el seno de las cuales se produjo una ciclogénesis. La baja formada se fue extendiendo a lo largo del periodo y acabó abarcando finalmente toda la Península. Se formaron dos centros de bajas presiones: uno en Argelia, y otro, en el entorno de Baleares a las 12 UTC del 22, que se fue desplazando hacia el nordeste. Esta última baja tenía asociado un sistema frontal, cuyo sector cálido penetró en Cataluña durante la segunda mitad del día 22 en forma de masa de aire cálido del Mediterráneo, con alta inestabilidad estática. La combinación de esta fuerte inestabilidad junto con la cizalladura vertical del viento dio lugar a convección organizada. Durante la tarde, se formó una zona de convergencias de viento sobre la zona frontal visible al sur de Cataluña que fue penetrando hasta el sur de Lleida (ver análisis mesoescalar más abajo).

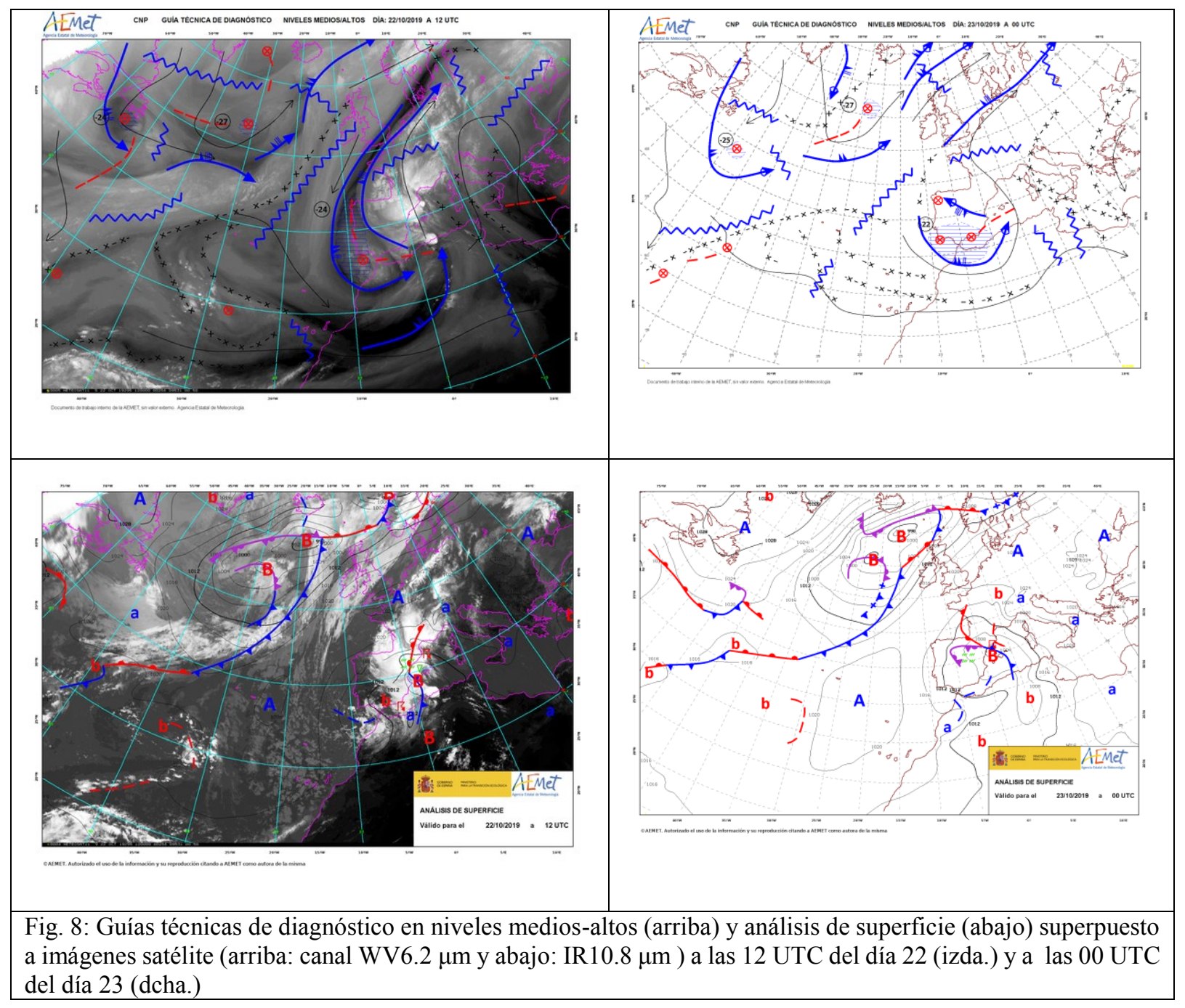


A las 00 UTC del día 23 (fig. 8), la baja centrada sobre el mar Balear (1004 hPa) afectaba especialmente a la mitad oriental de la península ibérica. Un complejo sistema de tres frentes (frío, cálido y ocluido) se situaba en torno al centro de la baja. Cataluña se encontraba aún bajo la masa cálida y húmeda de origen mediterráneo. El flujo sinóptico en superficie era moderado de componente E. Durante las primeras horas del día 23 las bajas presiones fueron abarcando la Península, extendiéndose hacia el norte y acoplándose con la dana en altura. Posteriormente el viento giró a $\mathrm{S}$ en toda la fachada mediterránea, aflojando.

En el nivel de $850 \mathrm{hPa}$ estaba presente una vaguada térmica sobre la Península, al principio sobre el oeste (00 UTC del día 22) y que se fue desplazando hacia el sur extendiéndose sobre la Península, dejando ligeramente exento al cuadrante nordeste. La temperatura a este nivel sobre Cataluña a las 12 UTC del día 22 era de $10-14{ }^{\circ} \mathrm{C}$ (lengua cálida relativa en $850 \mathrm{hPa}$ ), bajando a $8-10^{\circ} \mathrm{C}$ en la madrugada del 23, cuando la vaguada térmica se extendió, aunque rellenándose. El gradiente vertical de temperatura entre 850 y $500 \mathrm{hPa}$ era grande a las 12 UTC del día 22 (unos $30-32^{\circ} \mathrm{C}$ de diferencia) y, por tanto, había una elevada inestabilidad térmica. Sobre el levante peninsular se fue situando durante el periodo de estudio una masa húmeda bastante profunda en 850 y $700 \mathrm{hPa}$ (agua precipitable total de entre 30 y $35 \mathrm{~mm}$ en la mayor parte de Cataluña salvo el tercio norte, con valores de entre 35 y $40 \mathrm{~mm}$ en los litorales durante la tarde del día 22). Esto se debió fundamentalmente al flujo sinóptico moderado a fuerte del ESE en niveles bajos y medios, con largo recorrido marítimo, desde el norte de África hasta Cataluña, especialmente en el sur de la comunidad durante la tarde del 22.

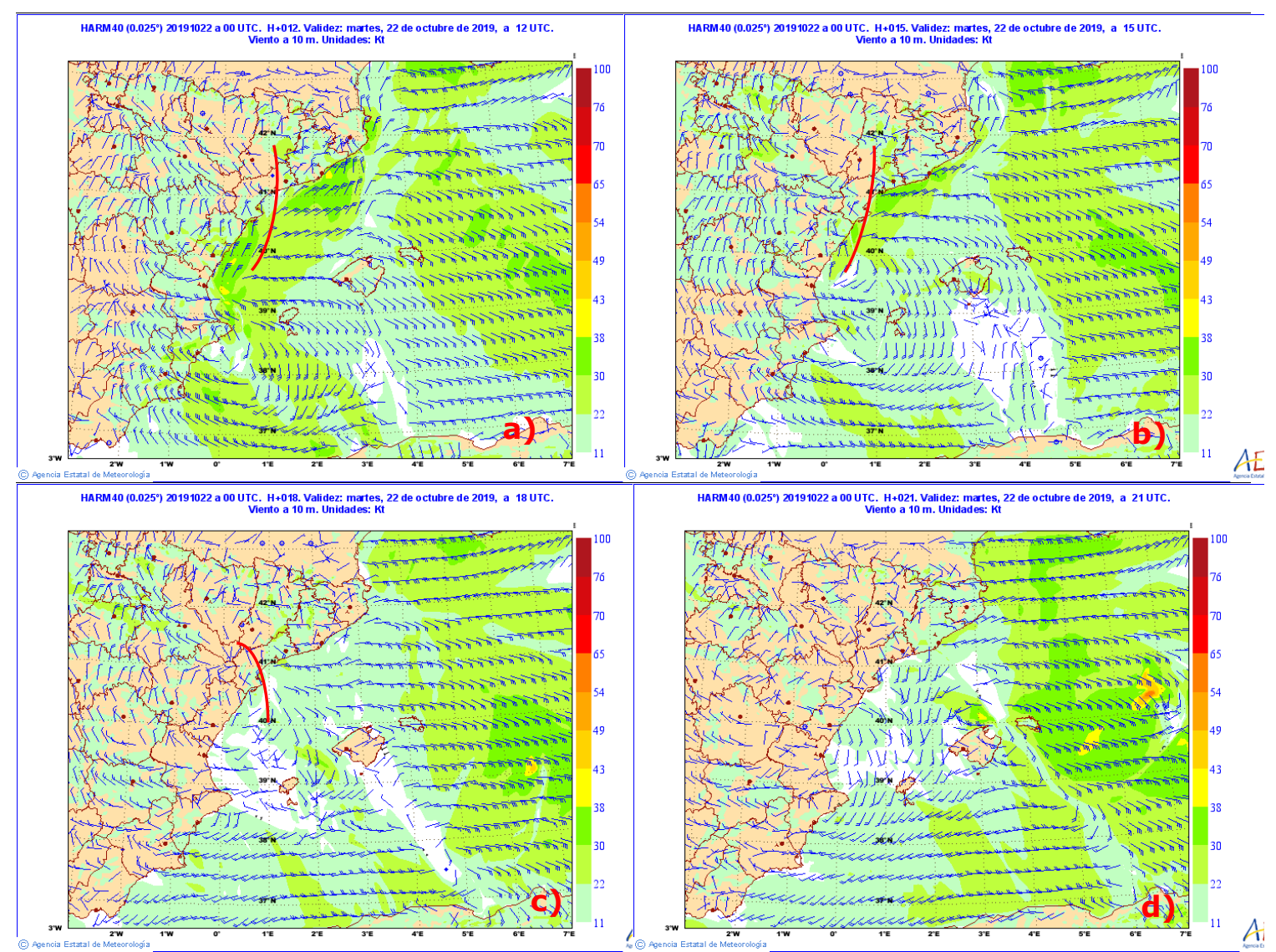

Fig. 9: Evolución del campo de viento en superficie previsto por el modelo HARMONIE-AROME durante la tarde del día 22: a) a las 12 , b) a las 15 , c) a las 18 y d) a las 21 UTC. 
Desde el punto de vista mesoescalar, a $925 \mathrm{hPa}$ el viento inicialmente era flojo del NE (10 kt aproximadamente) sobre Cataluña (00 UTC del día 22), virando a componente E e intensificándose (30-40 kt a las 12 UTC del 22). Los campos de viento (niveles bajos: superficie, $1000 \mathrm{hPa}, 925 \mathrm{hPa}$ ) de los modelos HRES-IFS del Centro Europeo de Predicción a Medio Plazo (ECMWF a partir de ahora) y HARMONIE-AROME (fig. 9) muestran una zona de convergencia bastante estacionaria sobre la zona donde ocurrió el episodio de lluvias torrenciales a partir de las 12 UTC del día 22, y que se fue desplazando hacia el nordeste, situándose entre las 21 del día 22 y las 00 UTC del 23 sobre la provincia de Barcelona y luego, entre las 00 y las 03 UTC sobre la de Girona. Dicha línea era coincidente al principio del episodio con el frente cálido.

Esta línea de convergencia fue determinante en la generación recurrente y la alineación de las células convectivas que conformaron el tren convectivo. El movimiento de las células convectivas sobre la línea estaba dirigido por el flujo rector en $700 \mathrm{hPa}$ (steering level), que durante el episodio era fuerte del SE sobre Cataluña ( $>30 \mathrm{kt}$ en gran parte del territorio durante la tarde del 22, desplazándose la zona de máximos hacia el nordeste en la madrugada del 23). Esta línea se formó hacia las 12 UTC sobre el tercio oeste de Cataluña, afectando al sur de Lleida y Tarragona, con orientación S-N, desplazándose hacia el oeste al principio para después avanzar hacia el nordeste, centrándose como una línea desfigurada sobre la depresión central de Barcelona a las 21 UTC, y continuar posteriormente su movimiento en la misma dirección. Los campos de convergencia del flujo de humedad, velocidad vertical y viento previstos por el modelo HRES-IFS (fig. 11) parecen delimitar dicha zona, también indicada como frontera por el parámetro frontal térmico (PFT).

La presencia de esta línea de convergencia se constata en las observaciones de viento medio horario registradas por la red de estaciones automáticas de AEMET (fig. 10). Este hecho se ve confirmado por el análisis de las imágenes de viento radial Doppler obtenidas por el radar de AEMET en Cataluña (ver más adelante, apartado 6) donde se aprecia una línea de convergencia visible intermitentemente que se va desplazando hacia el nordeste desde Tarragona.

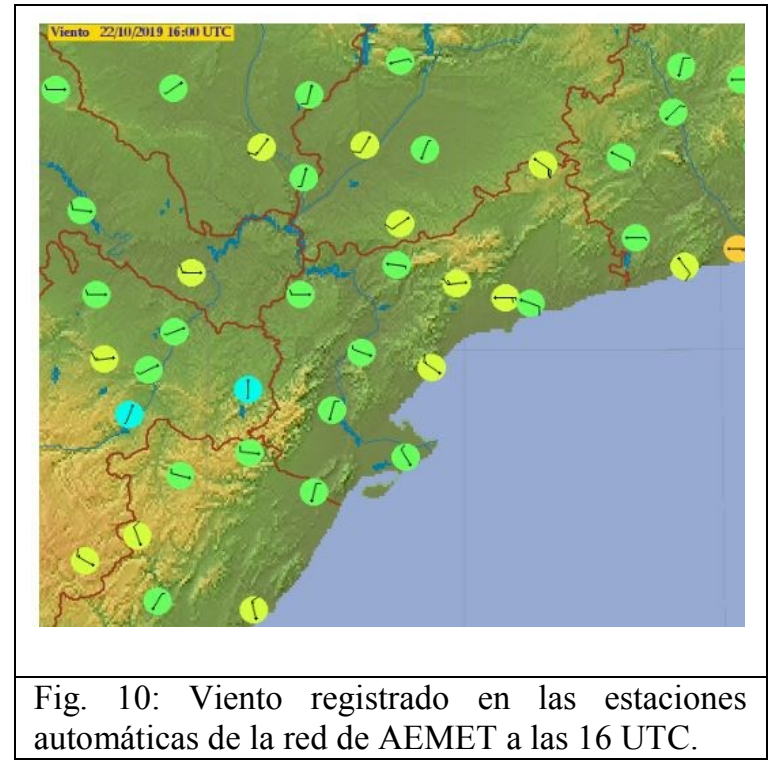


Las salidas del modelo HRES-IFS muestran una extensa zona de convergencia del flujo de humedad (fig. 11.a), presente desde las 12 UTC del día 22 que abarca gran parte de Tarragona y Lleida, sobre todo en niveles bajos (1000 y $925 \mathrm{hPa})$, que se fue desplazando hacia el nordeste. A las 15 UTC había una banda de convergencias fuertes en $1000 \mathrm{hPa}$ atravesando el norte de Tarragona hasta la mitad sur de Lleida, en la zona donde se produjeron las precipitaciones más intensas y copiosas, que permaneció casi estacionaria hasta las $00 \mathrm{UTC}$ del 23. A partir de las 00 UTC apareció otra zona relevante de convergencias en el nordeste de Cataluña, sobre los $925 \mathrm{hPa}$.

Esta zona de convergencia de humedad coincidía con una banda de valores elevados de PFT (fig. 11.b), visible en 925 y $850 \mathrm{hPa}$, presente desde las 12 UTC del 22 y casi estacionaria o con un ligero desplazamiento hacia el oeste. Después de las 21 UTC esta banda se fue desvaneciendo y apareció otra a las 00 UTC del 23 sobre Girona.

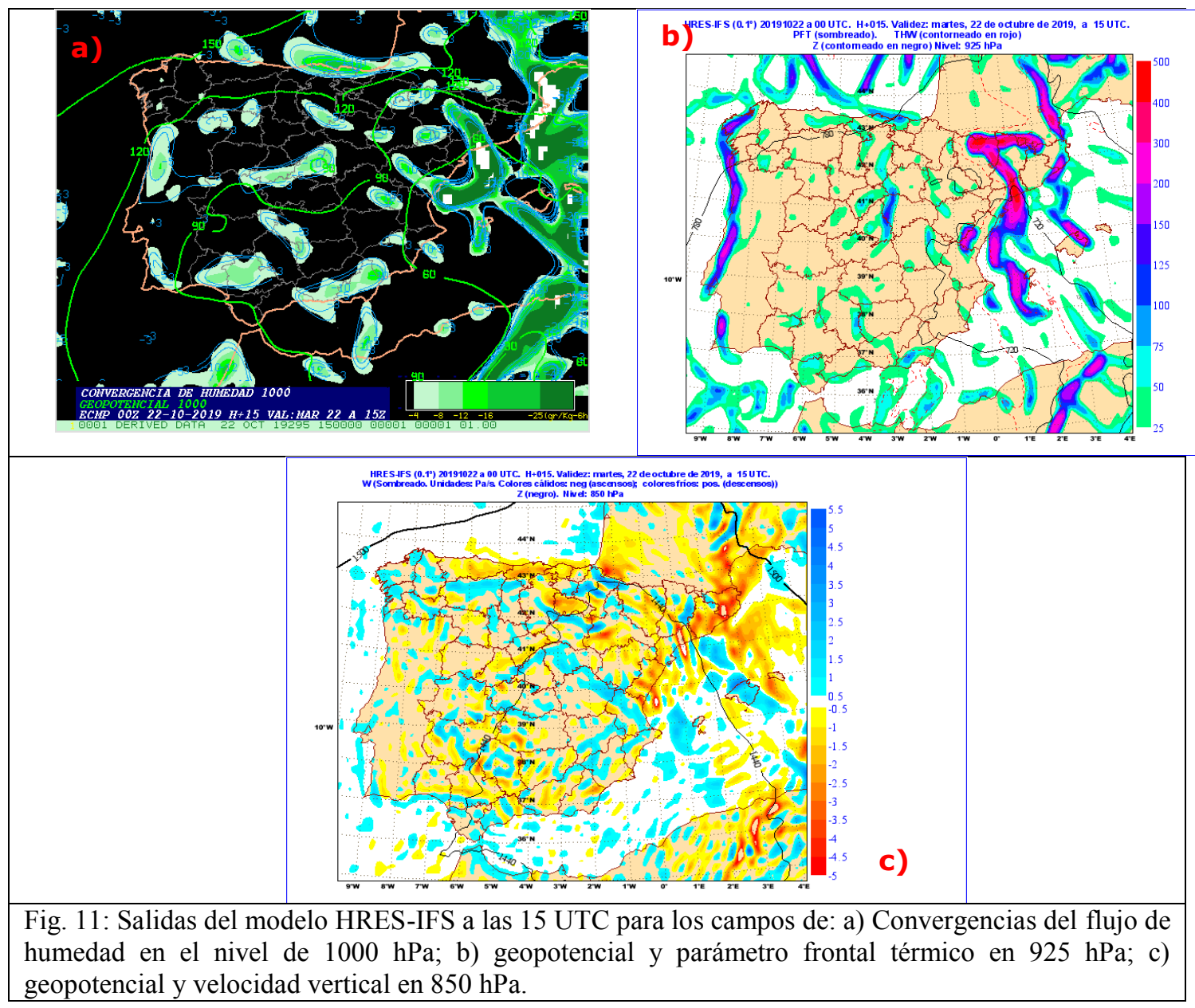

Los radiosondeos realizados desde Barcelona (tabla 6) mostraban índices de inestabilidad (LI, TT y K) con valores absolutos elevados a las 12 UTC del día 22, que sin embargo disminuyeron a las 00 UTC del 23 (salvo el CAPE que aumentó). En cambio, los sondeos previstos sobre la ciudad de Reus (cercano a la zona del Francolí) tanto por HRES-IFS como por HARMONIE-AROME (p.ej. fig. 12) reflejaban una inestabilización en el área entre las 12 y las 18 UTC del día 22 (ver tabla 6). También se observó una relevante cizalladura del viento en todos los perfiles. 


\begin{tabular}{|c|c|c|c|c|}
\hline Punto & K (12-00-12 UTC) & TT(12-00-12 UTC) & LI(12-00-12 UTC) & CAPE(12-00-12 UTC) \\
\hline Barcelona & $\mathbf{3 7 , 8}=>34,1=>19,5$ & $51,6=>47,2=>\mathbf{5 5 , 1}$ & $-0,8=>-0,4=>-\mathbf{4}, \mathbf{1}$ & $52=>153,9=>664,3$ \\
\hline $\begin{array}{l}\text { Palma } \\
\text { Mallorca }\end{array}$ & $\mathbf{3 9 , 4}=>34,1=>20,4$ & $\mathbf{5 4 , 9}=>47,3=>48,3$ & $-7,4=>-2,3=>-1,4$ & $\mathbf{2 3 0 2 , 5}=>0 \Rightarrow>271,2$ \\
\hline & K (12-15-18-21 UTC) & TT(12-15-18-21 UTC) & LI(12-15-18-21 UTC) & SBCAPE(12-15-18-21 UTC) \\
\hline $\begin{array}{l}\text { Reus } \\
\text { (HRES-IFS } \\
00)\end{array}$ & $\mathbf{3 6}, \mathbf{4}=>34,2=>32,2=>36,5$ & $51.5=>\mathbf{5 2 , 4}=>49,4=>51,3$ & $-0.7=>-1.3=>-\mathbf{2}, \mathbf{8}=>0,0$ & $127,9=>329,4=>\mathbf{3 5 9}, \mathbf{1}=>87,2$ \\
\hline $\begin{array}{l}\text { Reus } \\
\text { (HARMONIE- } \\
\text { AROME) }\end{array}$ & $32,7=>33,2=>\mathbf{3 5}, \mathbf{4}=>33,4$ & $46,6=>50,7=>\mathbf{5 3}, \mathbf{6}=>47,5$ & $2.9=>-1,6=>=>-6,2=>1,5$ & $\ldots=>334,0=>\mathbf{2 2 0 6}, \mathbf{8}=>61,5$ \\
\hline & $\begin{array}{l}\text { K= (T850 - T500) + }(\text { T850 } \\
\text { ROCIO) - (T700 - T700 } \\
\text { ROCIO ) } \\
\text { POSIBILIDAD D DE } \\
\text { TORMENTAS DE MASA } \\
\text { DE AIRE } \\
\text { MENORES DE } \\
\text { Alrededor del 0\% } \\
\text { ENTRE } 15 \text { Y } 2020 \% \\
\text { ENTRE } 21 \text { Y } 2520-40 \% \\
\text { ENTRE } 26 \text { Y } 3040-60 \% \\
\text { ENTRE } 31 \text { Y } 3560-80 \% \\
\text { ENTRE } 36 \text { Y } 4080-90 \% \\
\text { MENORES MAYORES DE } \\
\text { 40 Cerca del } 100 \%\end{array}$ & $\begin{array}{l}\text { TT }=(\mathrm{T} 850+\mathrm{T} 850 \\
\text { ROCIO) }-2(\mathrm{~T} 500) \\
\text { INTENSIDAD } \\
\text { COBERTURA ESPACIAL } \\
\text { DE LA TORMENTAS } \\
\text { VALOR DEL TOTAL DE } \\
\text { TOTALES } \\
\text { Tormentas aisladas } 48 \text { a } 52 \\
\text { Tormentas dispersas, } \\
\text { algunas de intensidad } \\
\text { moderada } 52 \text { a } 55 \text { dispersas, } \\
\text { Tormentas moderadas y } \\
\text { algunas } \\
\text { alguna aislada severa } 55 \text { a } \\
58 \\
\text { Tormentas moderadas } \\
\text { dispersas, algunas severas } \\
58 \text { a } 61 \text { frecuentes } \\
\text { Tormentas } \\
\text { moderadas, alguna severa } \\
61 \text { a } 64 \text { frecuentes, } \\
\text { Tormentas foras, con tormentas } \\
\text { moderadas, } \\
\text { severas }>64\end{array}$ & $\begin{array}{l}\text { LI: T500-T500 Burbuja } \\
\text { DE } 0 \text { A - } 3 \text { Posibilidad de } \\
\text { tormentas. Se necesita un fuerte } \\
\text { mecanismo de disparo } \\
\text { DE -3 A -5 Inestable. Probables } \\
\text { tormentas } \\
\text { MENOR DE -6 Muy inestable. } \\
\text { Puede haber tormentas fuertes } \\
\text { o severas }\end{array}$ & 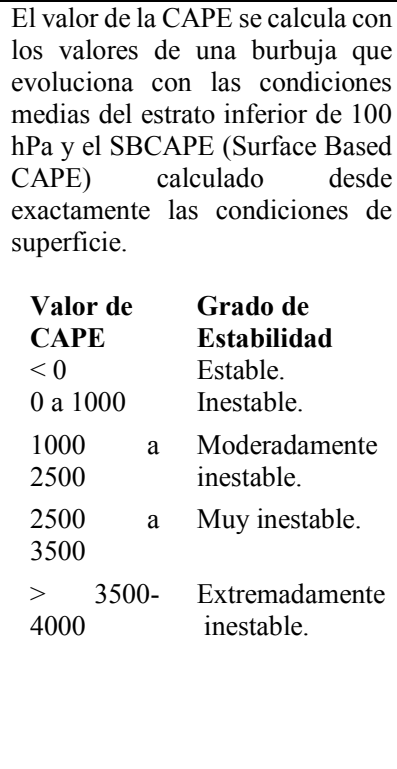 \\
\hline
\end{tabular}

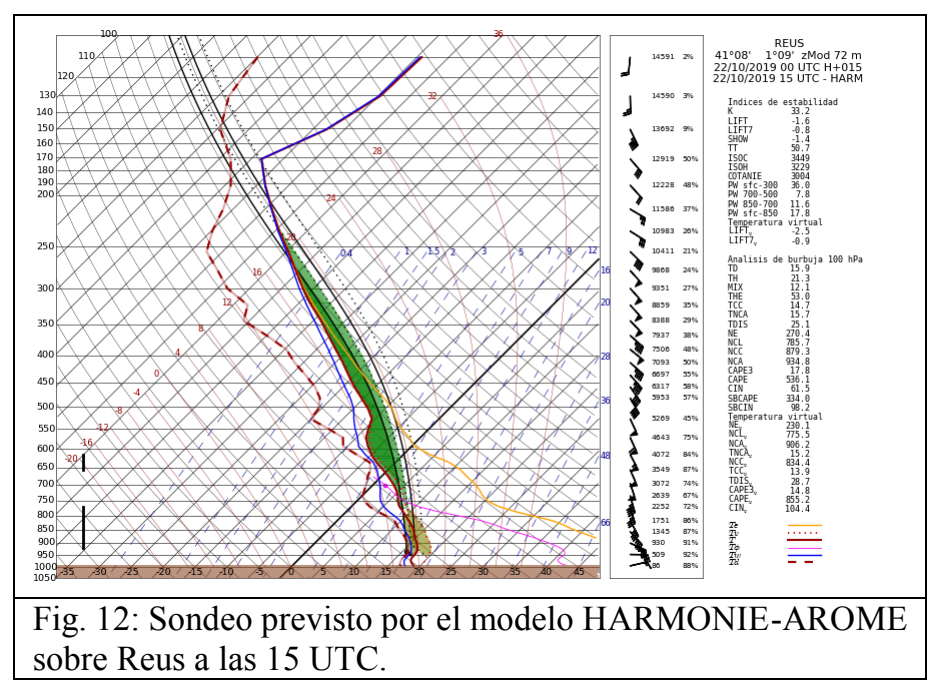

Los radiosondeos de Palma y Barcelona no presentaban unos valores muy significativos para los índices de inestabilidad durante el episodio del Francolí (entre las 12 UTC del 22 y 00 UTC del 23), aunque quizás no reflejan lo que pudo ocurrir en medio 
de ese periodo. El CAPE presentaba un valor muy elevado al principio en Mallorca y elevado a las 12 UTC del 23 en Barcelona, indicando el desplazamiento de la zona de inestabilidad (y las bajas presiones) hacia el norte-nordeste. La cizalladura del viento era marcada en Barcelona a las 00 UTC (viento del E en superficie virando al S en capas altas), hecho que habría contribuido a la organización de la convección, necesaria para que las corrientes ascendentes y descendentes no se solaparan, y la estructura convectiva principal perdurara en el tiempo.

En cuanto al CAPE, el modelo HRES-IFS mostraba un lóbulo con valores mayores del orden de $1000-1500 \mathrm{~J} / \mathrm{kg}$ en el litoral y el prelitoral de Tarragona a partir de las 12 UTC, que se fue desplazando hacia el nordeste (provincias de Barcelona y Girona) (fig. 13.izda). Asimismo, había valores de LI de 0 a -2 en la mitad norte de Tarragona que se fueron desplazando también hacia el nordeste, alcanzándose a las 00 UTC del día 23 valores comprendidos entre -2 y -4 en las franjas litoral y prelitoral de Barcelona y Girona. De igual forma, el modelo mostraba marcados ascensos en el sur de Tarragona a las 12 UTC (fig. 11.c) a todos los niveles, incluso a $500 \mathrm{hPa}$, que se desplazaron a las 15 UTC al norte de Tarragona, y al final del día se situaron sobre las provincias de Barcelona y Girona. También había cantidades considerables de agua precipitable total en toda la columna (35-40 $\mathrm{mm}$ ) sobre el litoral y el prelitoral debido al intenso flujo del E y SE en capas bajas. La señal de cizalladura en los $3 \mathrm{~km}$ más bajos de la troposfera era fuerte en la zona de las montañas de Prades durante la tarde del 22 (fig. 13.dcha), desplazándose este máximo, como en el caso de resto de índices, hacia el prelitoral y litoral del nordeste de Cataluña al final del día.

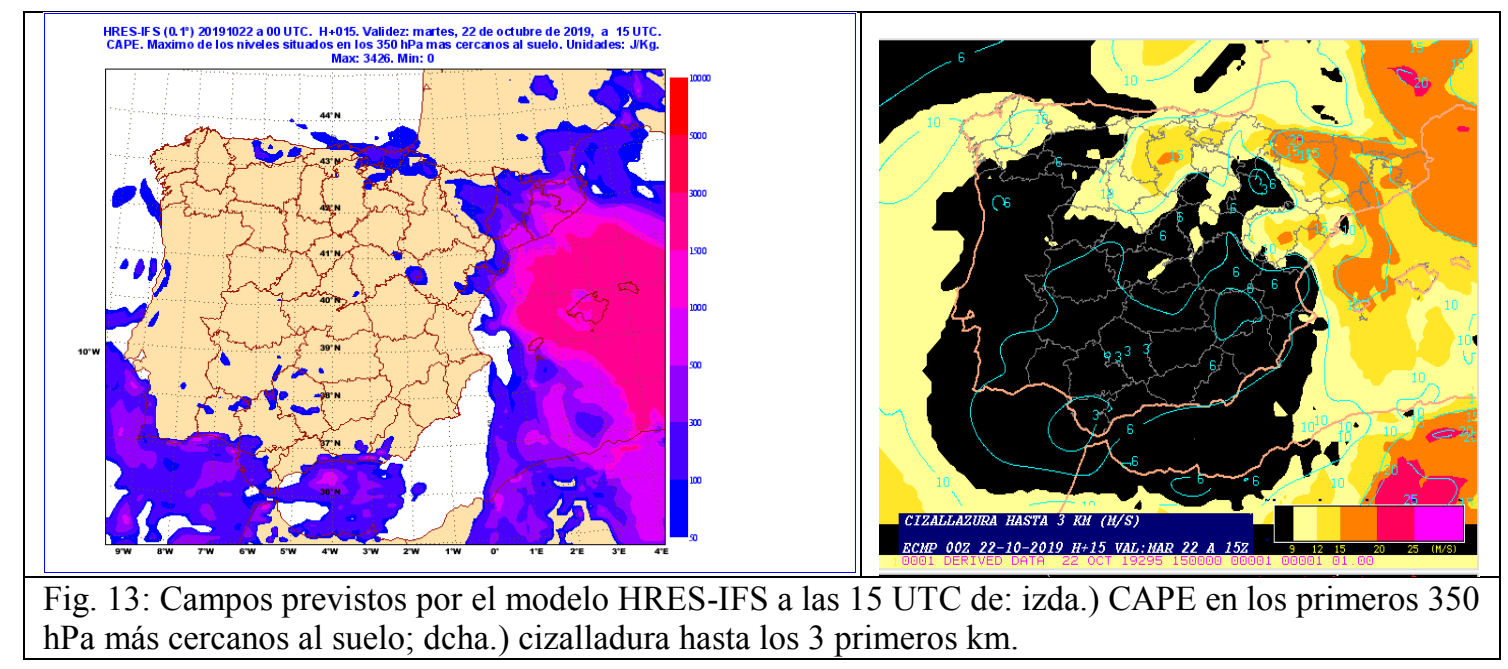




\section{Análisis de las estructuras convectivas}

En este apartado se presenta el estudio de la nubosidad, las estructuras precipitantes y las tormentas mediante las herramientas de teledetección.

El estudio de las imágenes de los canales, VIS0.6, WV6.2, IR10.8 y HRVIS del satélite Meteosat 10 ayuda a comprender el complejo proceso de convección que tuvo lugar en el Mediterráneo occidental y en la mitad oriental de la Península durante el periodo analizado, reforzado por la ciclogénesis que comenzó en el norte de Argelia.

Una extensa banda nubosa abarcaba el primer y segundo cuadrante de la dana, desde el norte de África hasta el centro de Francia, de forma más o menos continuada durante todo el día 22 (fig. 14), siendo el movimiento de la nubosidad inicialmente de sur a norte y más tarde, de sureste a noroeste, siguiendo el flujo rector en $700 \mathrm{hPa}$, a medida que la dana se fue desplazando hacia el sureste de la Península. Por tanto, el cielo estuvo muy nuboso o cubierto en Cataluña durante la mayor parte del día. Desde primera hora del día 22 (00 UTC), embebido en esta amplia banda nubosa, ya se había formado un sistema convectivo de mesoscala (SCM) al sur de Mallorca, de larga vida, que se fue desplazando hacia el norte hasta alcanzar Francia. Hacia las 05 UTC se formó otro SCM al suroeste de Ibiza que se fue desplazando hacia el nordeste (causando un tornado sobre la isla) y, luego hacia el noroeste, alcanzando su escudo de cirros el sur de Tarragona en torno a las 09 UTC.

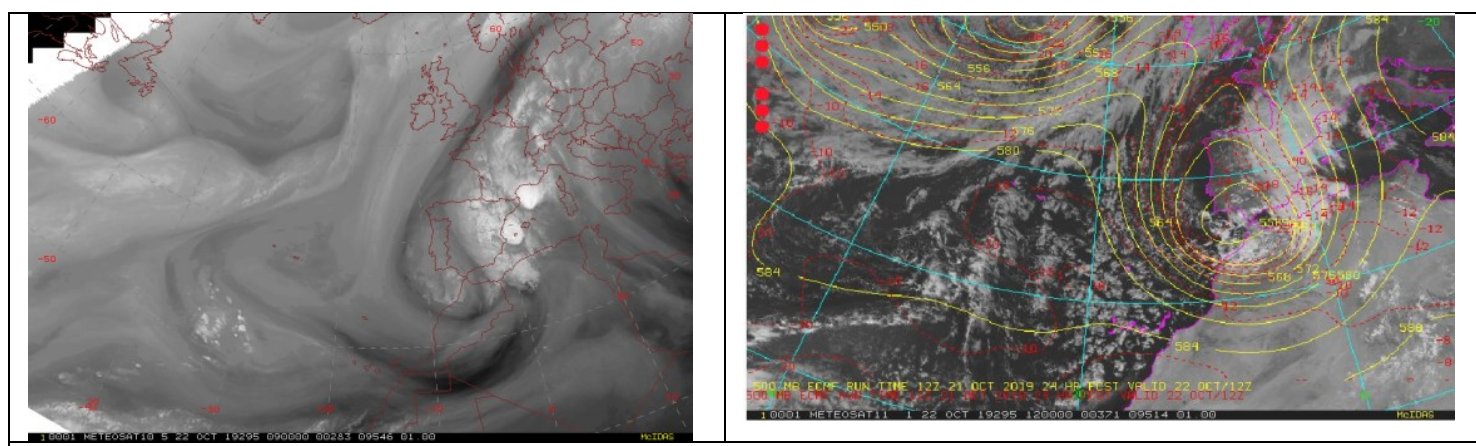

Fig. 14: Imágenes del satélite Meteosat: izda.) del canal de vapor de agua WV6.2 $\mu \mathrm{m}$ a las 9 UTC y dcha.) del canal VIS0.6 $\mu \mathrm{m}$ con campos de geopotencial y temperatura en $500 \mathrm{hPa}$ del modelo HRESIFS superpuestos para las 12 UTC.

Este SCM, con una forma alternante entre "U" y "V", redujo su extensión al llegar a la Península pero no su profundidad y penetró activo en Cataluña por su extremo sur. Permaneció casi estacionario sobre esta zona, con un ligero desplazamiento hacia el nordeste, y se reforzó y aumentó su extensión a partir de las 17:30 UTC. El realce (PREVIMET, aplicado al canal IR10.8 $\mu \mathrm{m}$ de Meteosat, fig. 15) mostraba que las temperaturas de brillo en los topes nubosos del sistema convectivo alcanzaban valores muy bajos, del orden de -64 a $-68^{\circ} \mathrm{C}$, indicadores de la gran profundidad de la convección. Esto pudo deberse a que una parte del territorio catalán quedó más descubierto a partir de las 12 UTC, con intervalos nubosos, pudiendo jugar un papel importante la radiación solar en un nuevo disparo de la convección y el mantenimiento del SCM nocturno. 

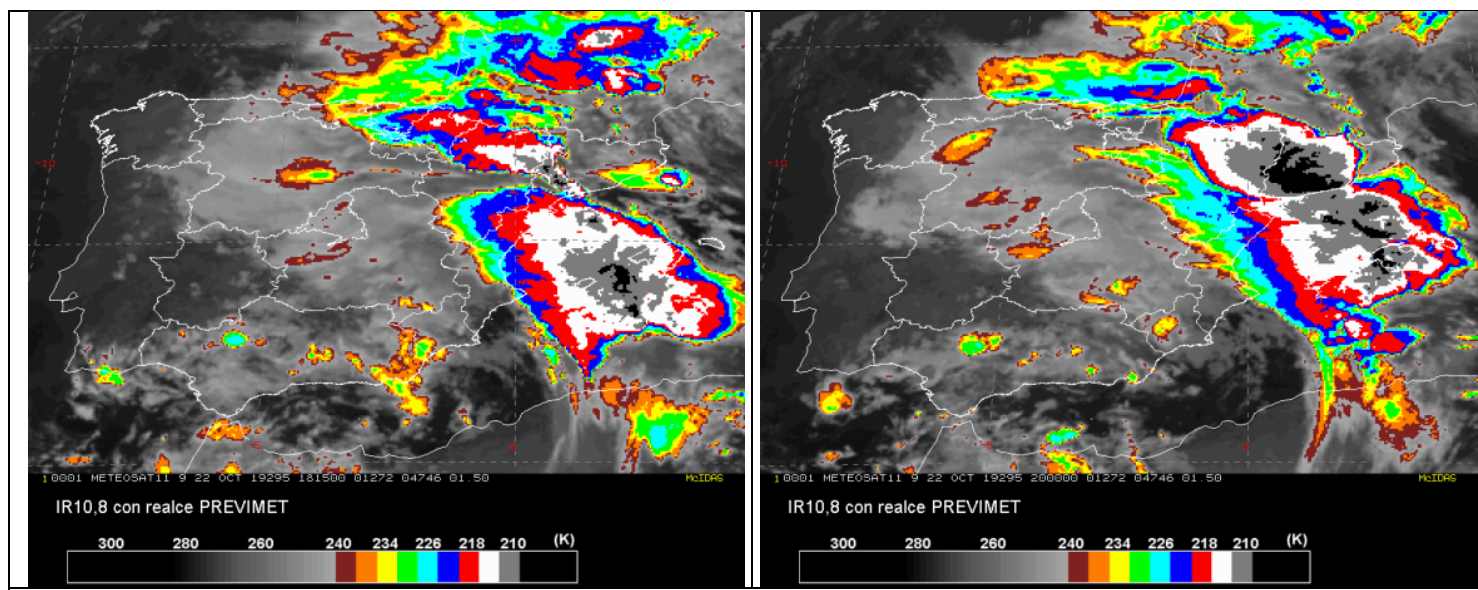

Fig. 15: Imágenes del canal IR10,8 $\mu \mathrm{m}$ de Meteosat con el realce PREVIMET para las: izda.) 18:15 UTC y dcha.) las 20 UTC.

A las 18-18:30 UTC dicho SCM se fusionó con otro situado más al sur, fruto de la convección profunda que se estaba desarrollando en el norte de Argelia asociada a la ciclogénesis, convirtiéndose en un amplio complejo convectivo de mesoscala (CCM), con temperaturas de brillo inferiores a $-32{ }^{\circ} \mathrm{C}$ sobre una extensión de más de $100.000 \mathrm{~km}^{2} \mathrm{y}$ por debajo de $-52{ }^{\circ} \mathrm{C}$ en una extensión superior a los $50.000 \mathrm{~km}^{2}$, que cubría prácticamente todo el cuadrante nordeste peninsular y Baleares. Este CCM se fue desplazando durante la noche del 22 y la madrugada del 23 hacia el norte-nordeste, trasladándose a Francia. De este modo la nubosidad y las precipitaciones fueron retirándose de suroeste a nordeste en Cataluña, quedando fuera de su radio de acción en torno a las 06 UTC, aunque siguió habiendo convección y precipitaciones durante las siguientes horas, pero mucho más débiles.

El análisis de las imágenes de reflectividad (Z PPI0) del radar de AEMET (fig. 16) en Cataluña del periodo analizado (del día 22 a las 00 UTC al 23 a las 12 UTC) revela un movimiento general de las precipitaciones y las células convectivas de sur a norte o de sureste a noroeste. A lo largo del día 22 se detectaron áreas extensas de precipitación débil o moderada, con pequeños núcleos de $\mathrm{Z}>48 \mathrm{dBZ}$ embebidos en estas áreas. Las precipitaciones en la provincia de Tarragona fueron generales y persistentes a partir de las 09:50 UTC y se fueron intensificando progresivamente. Los núcleos más intensos se generaron entre la costa de Castellón y la isla de Mallorca a partir de las 10:50 UTC, y se fueron trasladando hacia el norte entrando por el sur de la provincia de Tarragona. Dichos núcleos comenzaron a organizarse a partir de las 13:10 UTC en pequeñas líneas orientadas de sureste a noroeste, y se movieron de forma oblicua (no perpendicular a la línea).

La estructura más intensa y duradera fue el sistema convectivo de mesoescala que se formó hacia las 15:20 UTC al norte del delta del Ebro en forma de línea con orientación NW-SE, que se fue trasladando hacia el norte siguiendo la costa hasta las 16:00 UTC. Durante las 3 horas siguientes, hasta las 19:00 UTC, se mantuvo casi estacionaria desde la zona marítima frente a la costa central de Tarragona hasta el sur de la provincia de Lleida, con la misma orientación. El sistema alcanzó una longitud máxima del orden de $200 \mathrm{~km}$ a las 18:50 UTC (fig. 16) con muchos puntos con Z $>48 \mathrm{dBZ}$, y causando precipitación fuerte o muy fuerte y persistente. Entre las 19:00 y las 20:30 UTC se fue desplazando hacia el norte hasta llegar al sur de la provincia de Barcelona y centro de 
Lleida, donde se disipó. Continuaron las precipitaciones en el nordeste de Cataluña hasta la madrugada del día 23, pero sin organizarse en ninguna forma concreta.

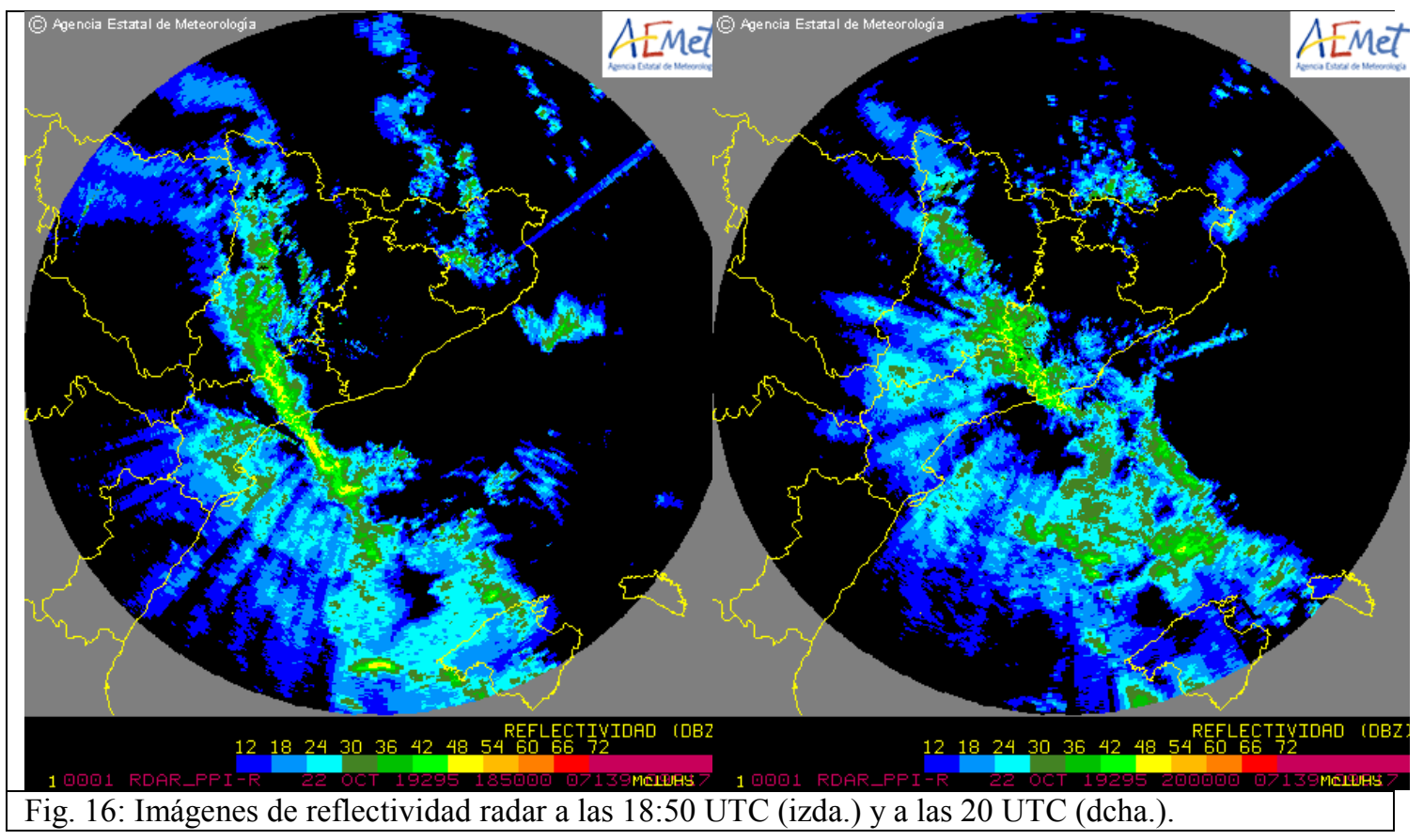

Se ha llevado a cabo un estudio detallado tanto de Z (fig. 16) como de las imágenes de acumulación radar (fig. 17) y de los registros de estaciones meteorológicas automáticas en la zona afectada por el tren convectivo (estaciones de Prades y l'Espluga de Francolí del SMC). Las primeras señales fuertes de Z (48 dBZ) se detectaron en l'Espluga de Francolí a las 11:10 UTC, y en Prades a las 11:30 UTC, y las últimas en Prades a las 18:50 UTC y en l'Espluga a las 19:20 UTC. La señal de Z en Prades fue más fuerte y persistente. Tanto en l'Espluga como en Prades se alcanzaron los $54 \mathrm{dBZ}$. Las últimas señales de precipitación se detectaron durante la madrugada del día 23.

En l'Espluga de Francolí se recogieron $156,7 \mathrm{~mm}$ entre las 00 UTC del 22 y las 00 UTC del 23, y en Prades 287,4 mm, de los cuáles 188,2 mm entre las 16 y las 19:30 UTC. El periodo de mayor intensidad en l'Espluga fue de las 18:45 a las 19:45 UTC, alcanzándose 41,4 mm/1 hora (intensidad muy fuerte), y en Prades el periodo más intenso ocurrió poco antes, de las 18:15 a las 19:15 UTC, registrándose $63,3 \mathrm{~mm} / 1 \mathrm{~h}$ (intensidad torrencial). El estudio de las imágenes de acumulación horaria radar confirmó que llovió más en la parte alta de las montañas que forman la cabecera del río Francolí: entre las 16 y las 20 UTC, entre 52-104 $\mathrm{mm}$ acumulados en Prades frente a los 40-80 mm de l'Espluga de Francolí.

Se debe señalar que los valores de acumulación por parte del radar pueden están subestimados debido a diversos efectos como la atenuación de la señal debida a las altas intensidades de precipitación en el camino del haz del radar o sobre el radomo, la elevación del haz, los asociados a la distancia como el aumento del tamaño del volumen de resolución radar o de otro tipo (tamaño del pixel: $1 \mathrm{~km}^{2}$ ) u obstáculos orográficos, la calibración del radar o la inexactitud de la relación Z-R usada. 


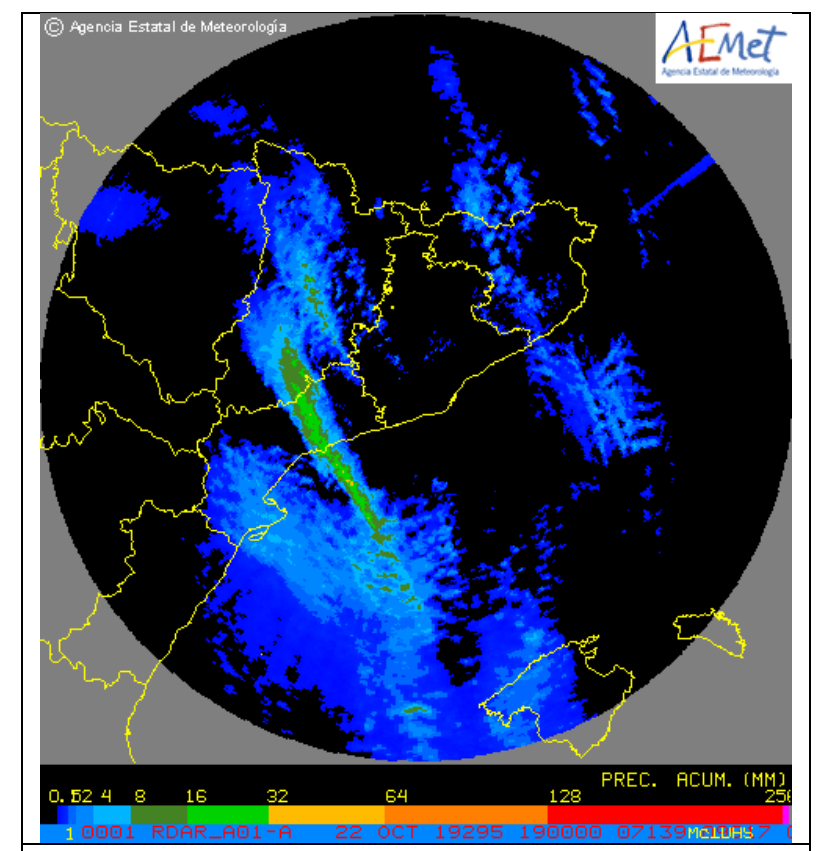

Fig. 17: Imagen del producto de acumulación de precipitación radar en la hora previa a las 19 UTC del día 22.

La distancia del radar a la zona de estudio es de aproximadamente $80 \mathrm{~km}$, por lo que la elevación del haz radar sobre ese punto es de $1 \mathrm{~km}$. Cabe destacar que en situaciones de alta eficiencia de la precipitación, como es el caso (mes de octubre, perfil vertical muy húmedo), el perfil vertical de reflectividad puede tener valores algo más altos en superficie que a $1 \mathrm{~km}$ de altura, por lo que la reflectividad pudo ser mayor que la detectada, y, por lo tanto, superior a $54 \mathrm{dBZ}$. En el periodo de mayor intensidad de los chubascos el área con precipitación no era tan extensa y no hubo atenuación del haz por la lluvia, y, además, la cobertura radar en la zona es razonablemente buena (no hay obstáculos orográficos significativos). Hubo caídas generales de $\mathrm{Z}$ cuando se dio precipitación moderada o fuerte sobre el radomo, pero no afectaron a los periodos de mayor intensidad en la zona de estudio. Por lo tanto, la principal causa de subestimación fue seguramente las elevadas intensidades de precipitación justo sobre las montañas de Prades, favorecidas por el ascenso orográfico forzado del aire húmedo e inestable.

El análisis de las imágenes del producto radar echotop (altura del eco de $12 \mathrm{dBZ}$ ) reveló una primera señal con valores entre $8-10 \mathrm{~km}$ entrando por la costa central de Tarragona a las 08 UTC, subiendo y alcanzando los $14-16 \mathrm{~km}$ por primera vez en el delta del Ebro a las 13:30 UTC. Coincidiendo con el periodo de lluvias más fuertes, se alcanzaron primero los 12-14 km en la zona afectada por el tren convectivo desde las 16 UTC, extendiéndose esta zona de gran profundidad y alcanzándose los 14-16 km a las 18:30 UTC. Hubo algo más de profundidad en Prades que en l'Espluga de Francolí. La estructura en línea con gran profundidad se mostró muy clara entre las 18:30 y las 19:00 UTC (fig. 18), desfigurándose posteriormente aunque conservando gran extensión y profundidad. La gran estructura convectiva era multicelular con aspecto de línea de turbonada con parte estratiforme en el extremo norte de la línea (parallel stratiform-el efecto de "tren convectivo" resulta de una organización linear de las tormentas, Doswell et. al, 1996). No se han encontrado, sin embargo, indicios de supercélulas. Durante el episodio se llegaron a alcanzar los 14-16 km sobre Cataluña, e incluso alturas mayores sobre el mar Balear. 


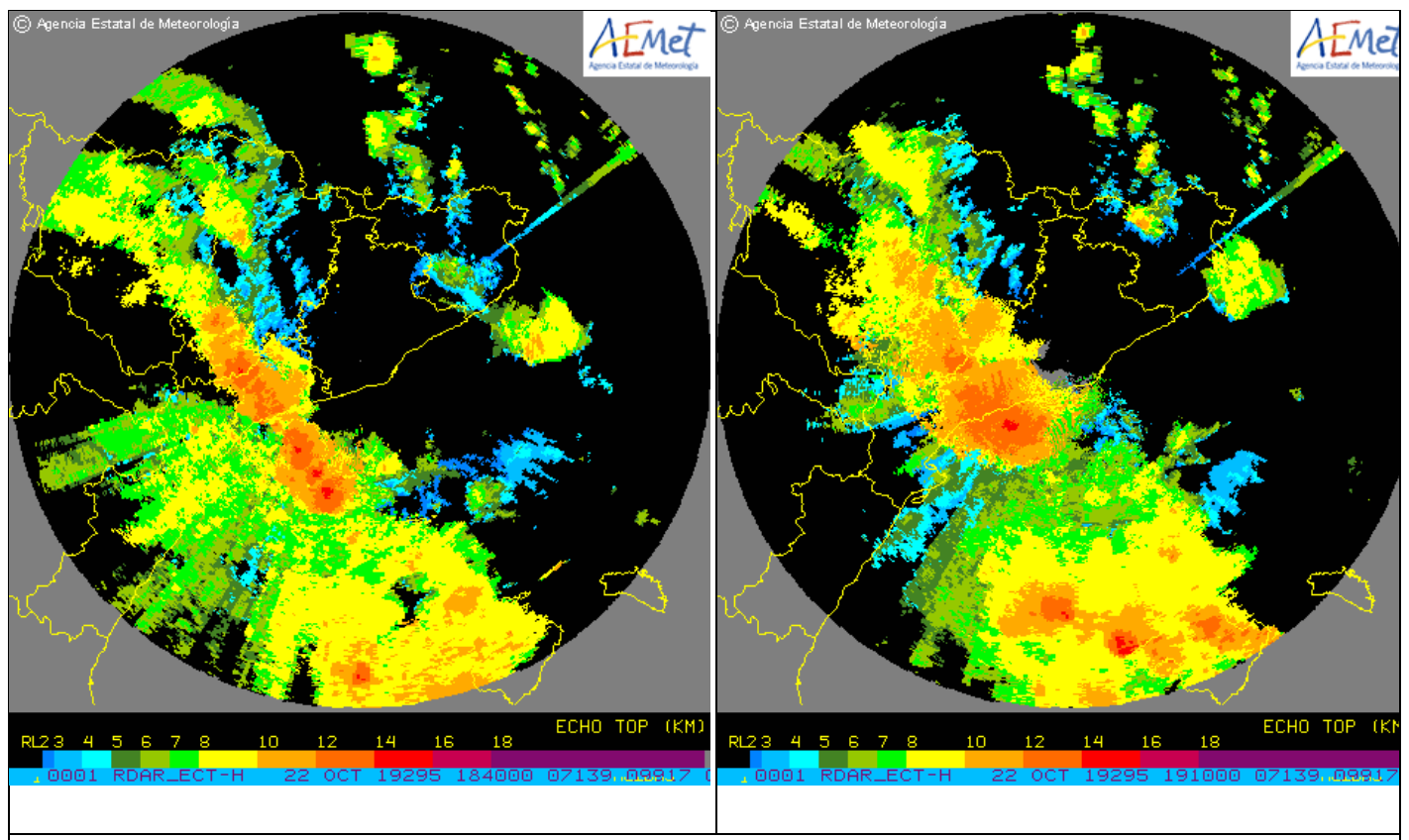

Fig. 18: Imágenes del producto de echotop del radar de Barcelona para el día 22 a las 18:40 (izda.) y a las 19:10 UTC (dcha.).

Se ha realizado también un estudio de las imágenes del producto de velocidad radial del radar en modo Doppler (fig. 19). A las 15 UTC del día 22 apareció una línea de convergencia, con orientación NW-SE, que se fue desplazando hacia el nordeste, coincidiendo con varias líneas de células radar detectadas en el campo de reflectividad radar que se orientaban y se desplazaban de igual forma. Esta línea de convergencia es consistente con las observaciones convencionales y con diversos campos numéricos disponibles (vientos en niveles bajos, convergencia del flujo de humedad, ascensos, PFT...).

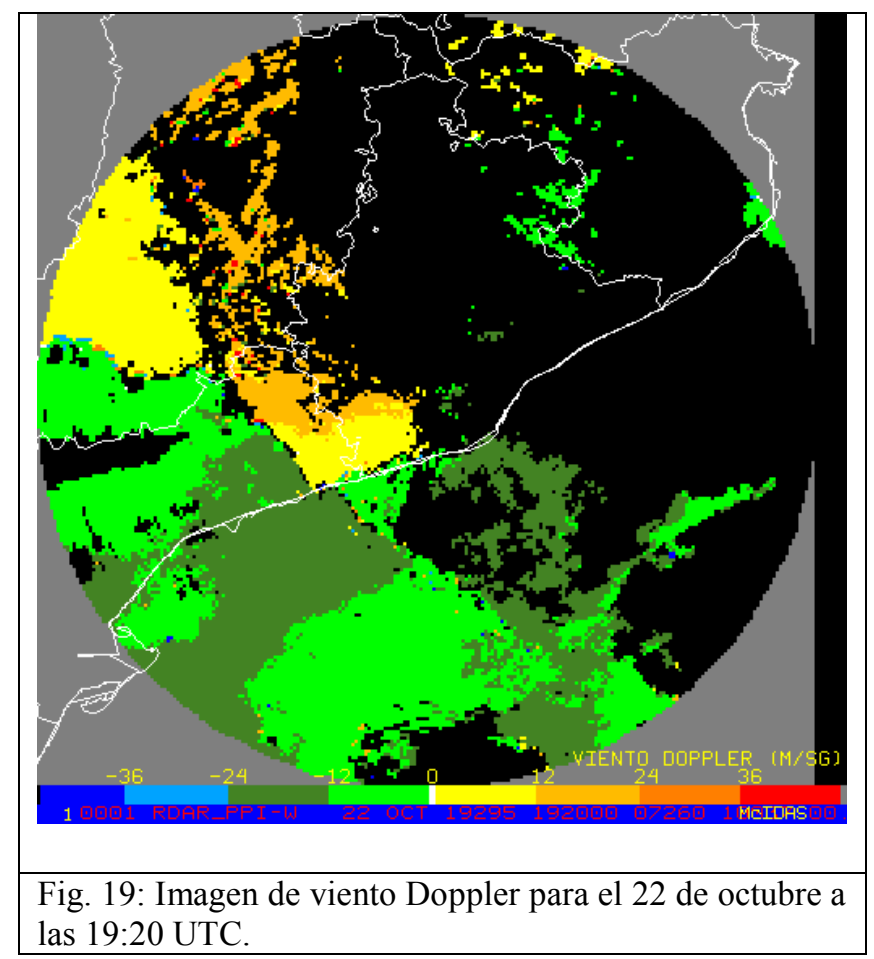


En el seno de dicha línea de convergencia mesoescalar se fueron generando diferentes estructuras convectivas pequeñas hasta que se desarrolló una masa grande, el tren convectivo citado anteriormente, que finalmente se trasladó hasta la provincia de Barcelona. A las 16:20 UTC la línea se enderezó ligeramente adquiriendo una orientación NNW-SSE y se situó sobre la zona donde se formó el tren convectivo. A las 18:30 UTC se localizó nítidamente en la zona de estudio donde se mantuvo estacionaria (fig. 19) hasta las 19:10 UTC cuando comenzó a desplazarse hacia el nordeste. A las 19:50 UTC dicha línea penetró en la provincia de Barcelona, comenzando a deshacerse.

El análisis de los datos procedentes de la red de detección de descargas eléctricas de AEMET muestra también aspectos del episodio muy interesantes. Entre las 08 UTC del día 22 y las 08 UTC del día 23 la red registró un elevado número de descargas (fig. 20), con un total de $\mathbf{1 6 2 2 4}$ impactos (en todo el área de la red, aunque la mayor parte se correspondían con la convección en el Mediterráneo). Hay que recordar que cada rayo puede tener asociado uno o varios impactos.

Antes de las 08 UTC del día 22 la señal de $Z$ radar no superó los $42 \mathrm{dBZ}$ en ningún lugar de Cataluña. El mayor número de descargas eléctricas se produjo entre las 20 UTC del día 22 y las 04 UTC del día 23 siendo el segundo periodo más activo entre las 12 y las 20 UTC del día 22. En la zona de estudio las descargas se produjeron entre las $16 \mathrm{y}$ las 20 UTC, coincidiendo con el periodo en el que $\mathrm{Z}$ y la intensidad de precipitación son máximas. Las descargas muestran un clarísimo desplazamiento de sur a norte y de suroeste a nordeste, acompañando a la estructura mesoescalar en línea presente en la señal radar.

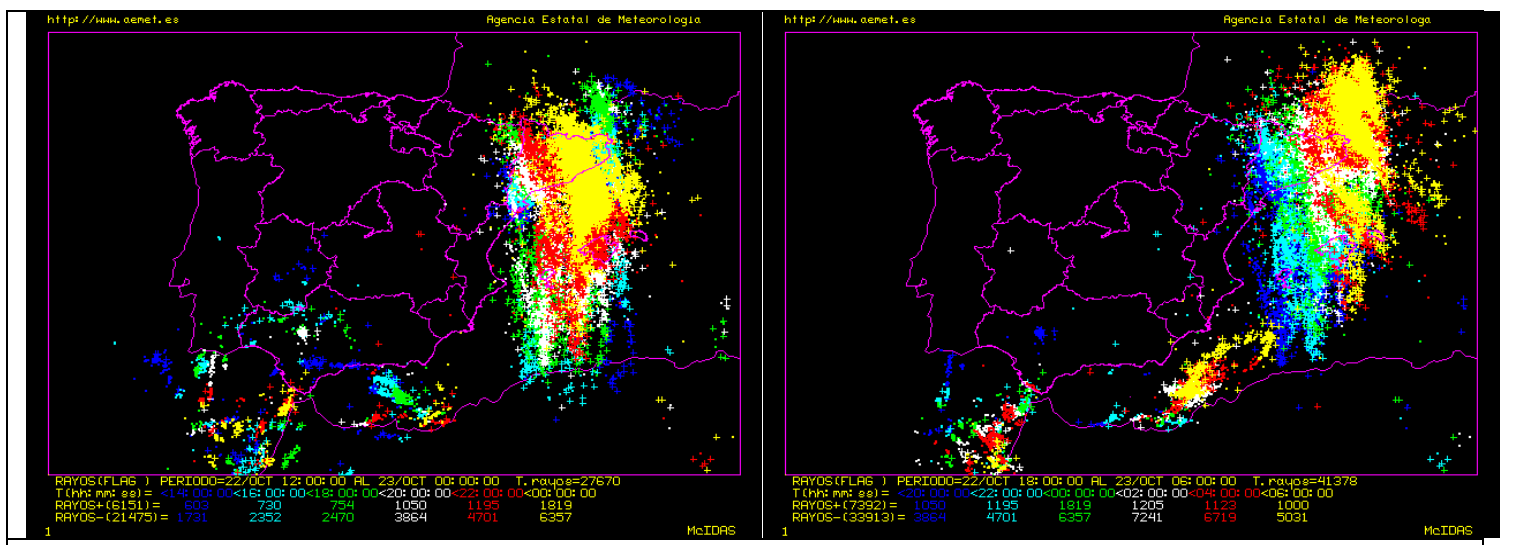

Fig. 20: Descargas eléctricas detectadas entre: izda.) las 12 UTC del día 22 y las 00 UTC del día 23 (colores correspondientes a intervalos de dos horas) y dcha.) las 18 UTC del 22 y las 06 UTC del 23.

En un análisis detallado de las descargas detectadas en torno a Prades y l'Espluga de Francolí entre las 16 y las 21 UTC (se han tomado dos círculos de radio $10 \mathrm{~km}$ en torno a cada población, separadas entre ambas $13 \mathrm{~km}$, ver fig. 21), se ha observado que la frecuencia elevada de descargas eléctricas empezó antes en el entorno de Prades que en l'Espluga de Francolí, siendo también esta frecuencia temporal mucho mayor en Prades (extremadamente alta entre las 18:30 y las 19:00 UTC - 9,7 impactos por minuto coincidiendo casi con la mayor cantidad de precipitación caída en $30 \mathrm{~min}$ : 44,2 mm entre 
las 18:15 y las 18:45 UTC). Las descargas acabaron más tarde en l'Espluga mostrando el desplazamiento hacia el norte de la tormenta, como se ha observado también en las imágenes radar. Sin embargo, las precipitaciones muy fuertes en Prades empezaron antes que el incremento fuerte en el número de impactos.

Tanto en la distribución espacial de las descargas eléctricas como de las precipitaciones registradas y la reflectividad radar, está claro que en la zona montañosa situada entre l'Espluga de Francolí y Prades (Montañas de Prades) la intensidad de la precipitación debió ser torrencial durante casi tres horas, lo que conllevó probablemente una acumulación de precipitación del orden de $200 \mathrm{~mm}$ en 3,5 h. En las subcuencas de Milans, Viern y Peguera se superaron los $250 \mathrm{~mm}$ de acumulación y en la parte alta de la del Francolí los $225 \mathrm{~mm}$ (Vide et al., 2020). Esto provocó, como se ha comprobado sobre el terreno (archivo fotográfico R. Pascual, no mostrado) súbitas y fuertes crecidas en los torrentes de montaña que descienden hacia el norte hasta confluir sus aguas en el río Francolí (afluentes de diversos grados). Las lluvias registradas en la sierra de Prades justifican que los caudales registrados en el río Francolí fueran más altos en cabecera proporcionalmente a los registrados en su desembocadura (ACA, 2019).

El análisis de las descargas a una escala algo mayor (40 km de radio del círculo) mostró que dentro del tren convectivo cuasi-estacionario situado en la provincia de Tarragona, la mayor densidad espacial de impactos entre las 16 y las 20 UTC se produjo precisamente en la zona analizada y entre las 18:30 y las 19:20 UTC. Se observó también una máxima concentración algo más al norte de la zona analizada, la alineación NW-SE del tren entre las 17:15 y las 19:30 UTC y su desplazamiento en conjunto hacia el norte. A las 18:30 UTC se detectaron los echotops más elevados en la zona de estudio (14-16 $\mathrm{km})$, mostrando la gran profundidad de la convección, así como los mayores valores de $\mathrm{Z}$, comprendidos entre los 48 y los $54 \mathrm{dBZ}$.

Las descargas eléctricas fueron mayoritariamente de signo negativo en todos los periodos de 30 minutos analizados. Cabe destacar que no se reportaran en este episodio ni granizo grande ni vientos fuertes de origen convectivo (lo que se conoce en la terminología anglosajona como severe weather), asociados a menudo a las descargas positivas. Este episodio estuvo caracterizado por los chubascos de intensidad muy fuerte o torrencial y la elevada copiosidad de la precipitación, debido a la persistencia de las lluvias fuertes.

Tras este análisis y el análisis de la situación meteorológica a mesoescala se puede concluir que las Montañas de Prades en su conjunto realzaron la convección profunda ligada al tren convectivo asociado a la línea de convergencia mesoescalar. Por tanto, se trató nuevamente de un flash-flood asociado a orografía compleja. 


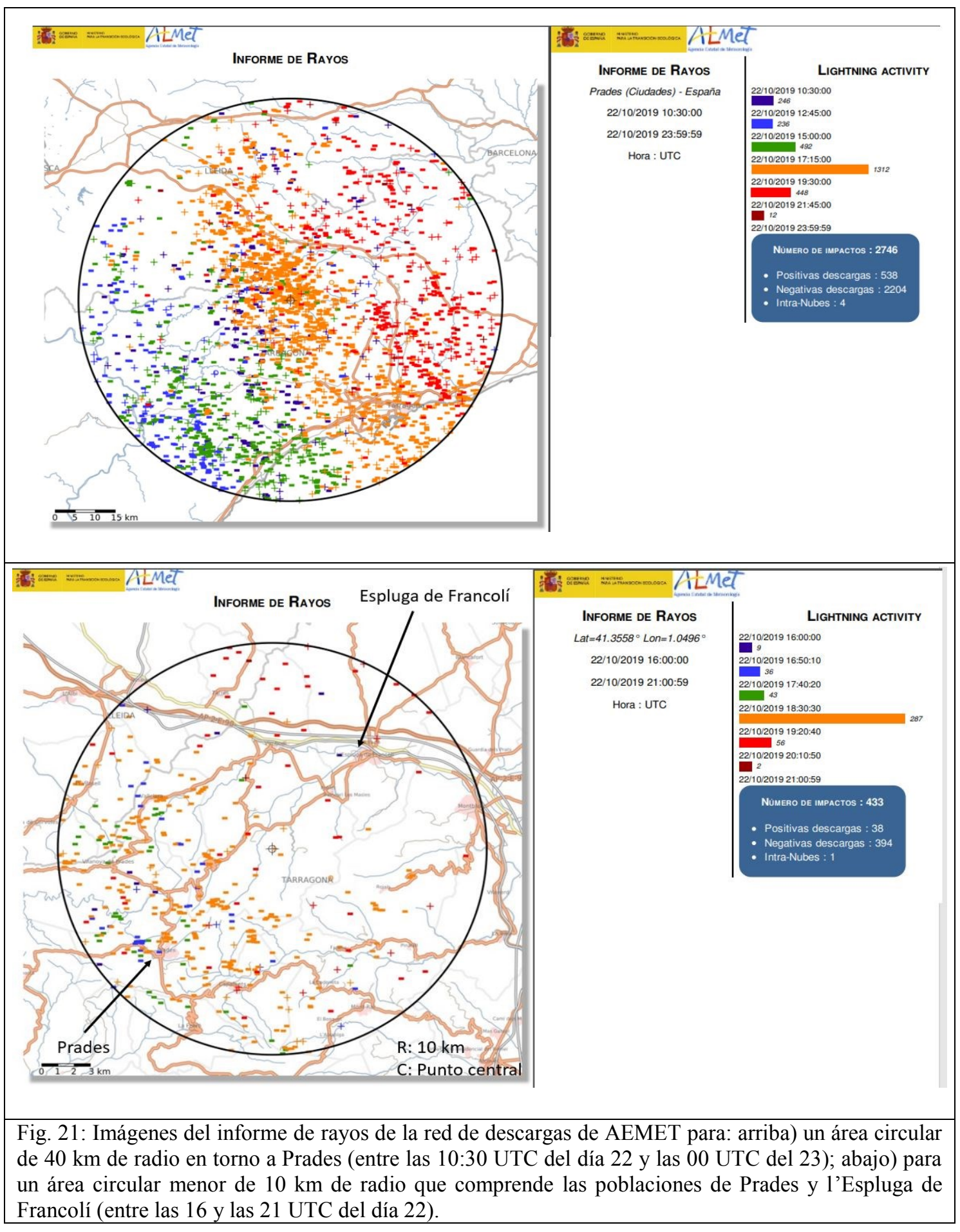




\section{Comportamiento de los modelos numéricos operativos}

En este apartado se presenta un análisis del comportamiento de los distintos modelos numéricos operativos en AEMET en este episodio para el campo de precipitación, con el fin de comprender mejor la predictibilidad del mismo. En principio, para dicho análisis se han tenido en cuenta en todos los modelos las pasadas operativas disponibles a las 08:30 UTC del día 22, momento de actualización de la predicción general y los avisos de fenómenos adversos para el día en curso por parte del Grupo de Predicción y Vigilancia de Barcelona. En concreto, se analizaron tanto modelos deterministas (hidrostático global HRES-IFS y no hidrostático mesoescalar HARMONIE-AROME) como productos probabilistas de los ensembles ENS-IFS ECMWF y AEMET- $\gamma$ SREPS.

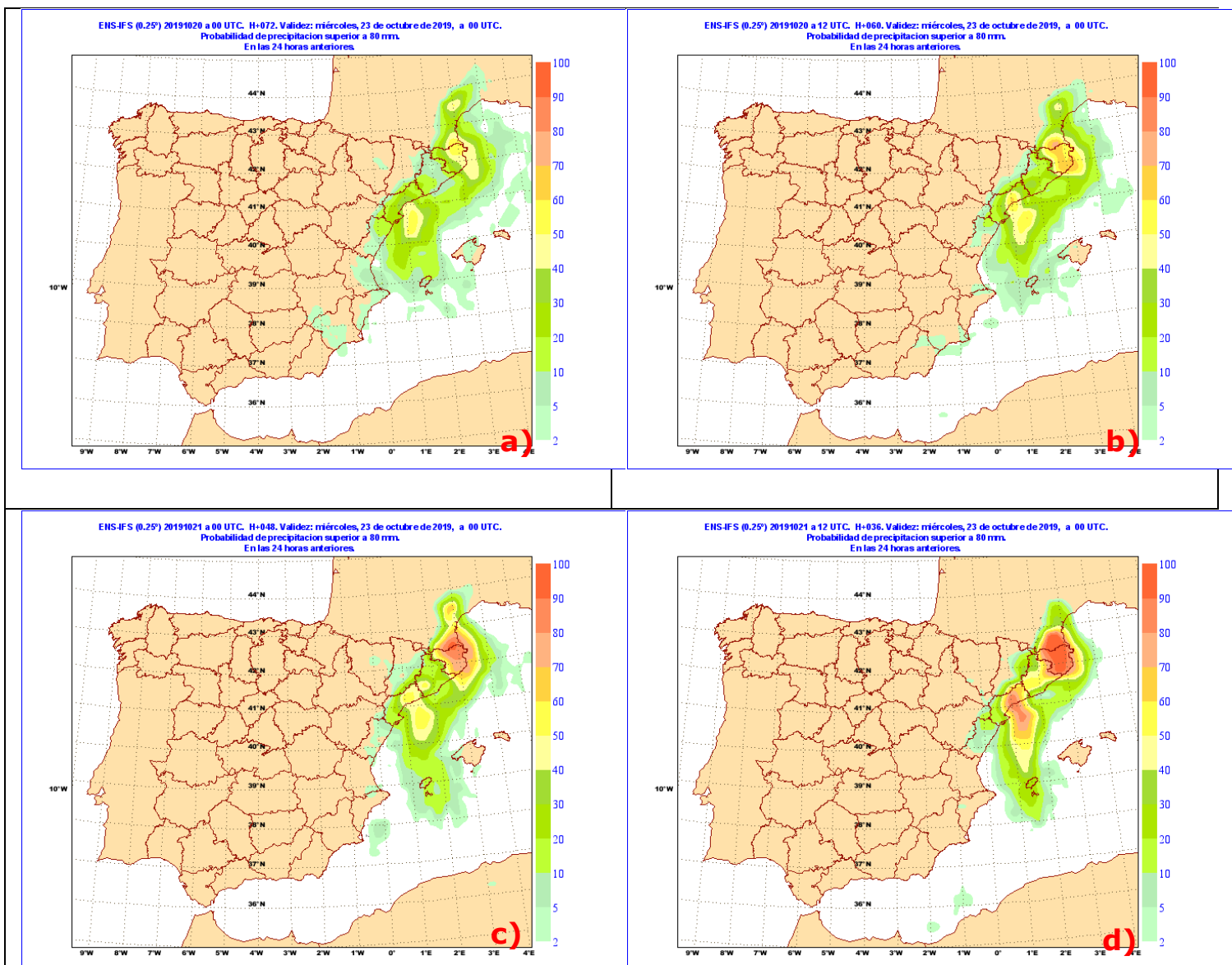

Fig. 22: Probabilidades del modelo ENS-IFS (ECMWF) de precipitación superior a $80 \mathrm{~mm} / 24 \mathrm{~h}$ de las pasadas de: a) las 00 UTC del día 20, b) las 12 UTC del día 20, c) las 00 UTC del día 21, d) las 12 UTC del día 21.

El día 20 el ensemble ENS-IFS ECMWF ya mostraba el paso de la dana, con poca dispersión entre sus miembros en cuanto a su posición. Las pasadas de las 00 y de las 12 UTC de ese día (fig. 22.a y b) reflejaban una cierta probabilidad (60-70\% la pasada de las 12 UTC) de precipitaciones abundantes $(>80 \mathrm{~mm} / 24 \mathrm{~h})$ en el nordeste de Cataluña. Las correspondientes pasadas del día 21 (fig. 22.c y d), el día previo al episodio, muestran aún más concordancia entre sus miembros, confirmándose en la pasada de las 00 UTC una probabilidad de precipitaciones en el nordeste de Cataluña superiores a $80 \mathrm{~mm} / 24 \mathrm{~h}$ del $60-90 \%$ y superior al $90 \%$ en puntos del Pirineo oriental) con una señal secundaria 
de 40-60 \% en la zona norte de la provincia de Tarragona, coincidente con la zona del "tren convectivo". Dichas probabilidades en ambas zonas se incrementan en la pasada de las 12 UTC a 80-90 \% en Tarragona, y en el nordeste se amplía la zona con probabilidades mayores de $90 \%$ de superar los $80 \mathrm{~mm} / 24 \mathrm{~h}$.

Las salidas del modelo determinista HRES-IFS (campos de precipitación acumulada en $24 \mathrm{~h}$ ) también han sido analizadas para diferentes pasadas (fig. 23): desde la del día 20 de octubre a las 12 UTC hasta la de las 00 UTC del día 22 (última disponible a la hora de elaboración de la predicción). Se ha tomado la franja de $24 \mathrm{~h}$ comprendida entre las 06 UTC del día 22 y las 06 UTC del día 23. Se ha constatado que todas las pasadas reflejan mayores acumulaciones en las provincias de Tarragona, Barcelona y Girona, con un máximo en el nordeste en Girona. La pasada del día 21 a las 12 UTC incluso sobrestimó la cantidad total de precipitación recogida $(>250 \mathrm{~mm} / 24 \mathrm{~h}$ previstos frente a los $160-180$ $\mathrm{mm}$ observados en la provincia de Girona para ese periodo) En cambio, hubo una subestimación de la precipitación recogida en las provincias de Tarragona y sur de Lleida, probablemente debida a que el tren convectivo de tormentas no fue generado con precisión por el modelo, aunque sí creó algo similar a una banda de precipitación que cruzaba de oeste a este la provincia de Tarragona. Sin embargo, esta banda se desdibujó en la última pasada disponible.

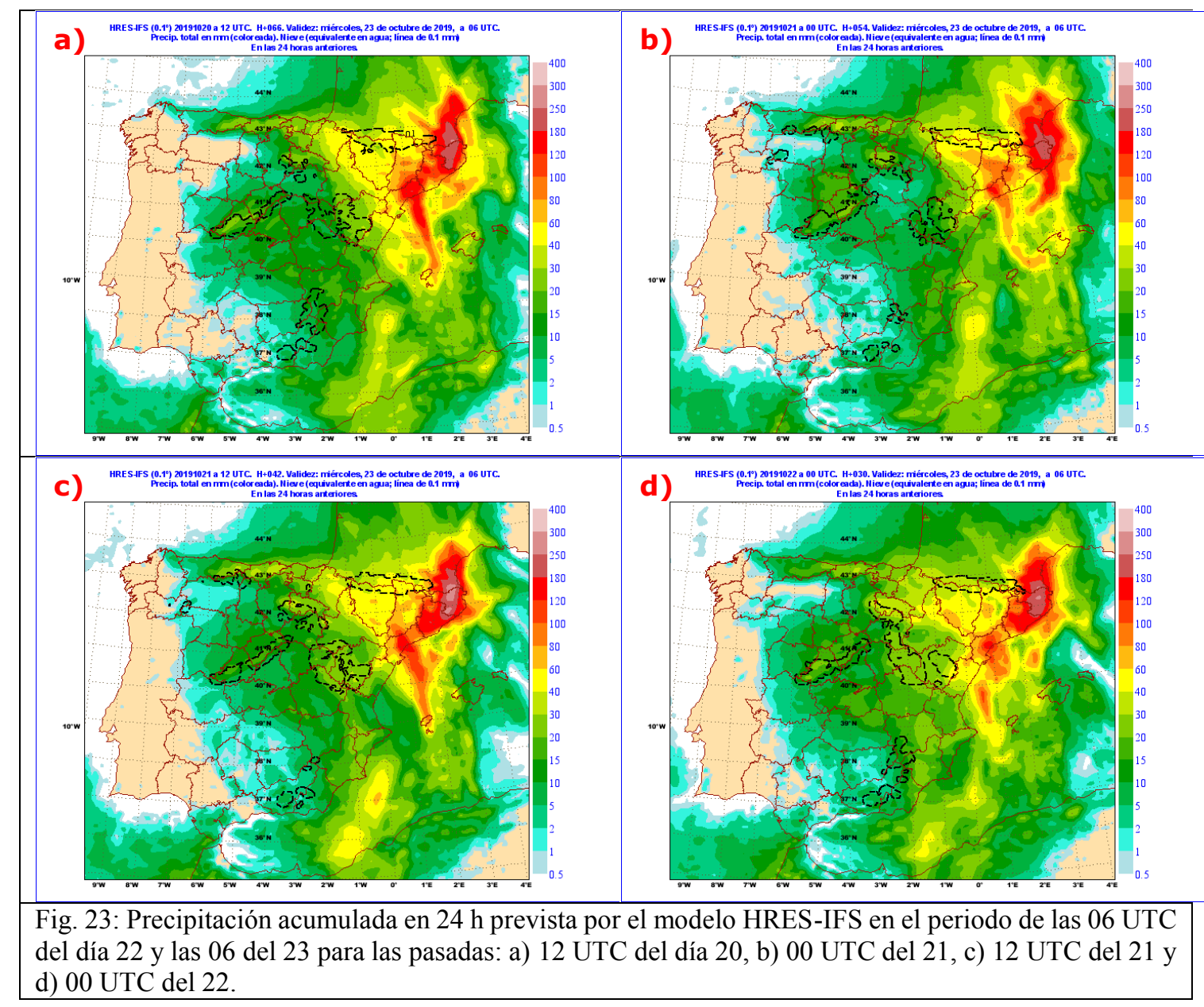

HARMONIE-AROME fue el modelo que peor simuló el episodio de lluvias. No solo la localización de los máximos de acumulación no se correspondió con la realidad, sino que también presentó una subestimación importante (fig. 24). 


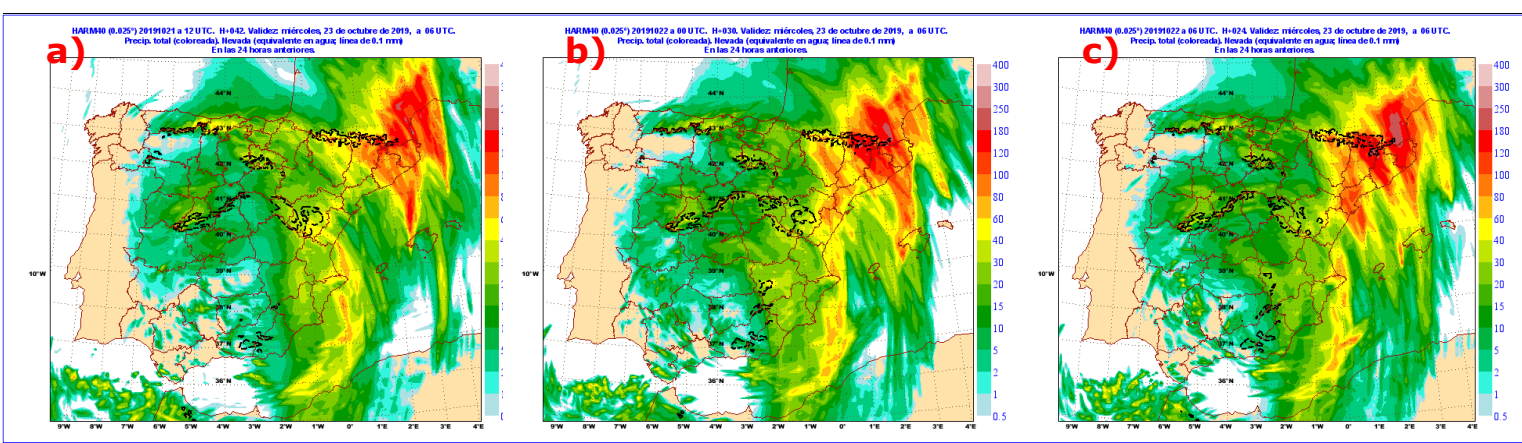

Fig. 24: Precipitación acumulada en $24 \mathrm{~h}$ prevista por el modelo HARMONIE-AROME en el periodo de las 06 UTC del día 22 a las 06 del 23 para las pasadas: a) 12 UTC del día 21, b) 00 UTC del 22 y c) 12 UTC del día 22.

Las zonas o bandas de precipitación más abundante $(120-180 \mathrm{~mm} / 24)$ fueron situadas principalmente sobre el cuadrante nordeste de Cataluña, asemejándose bastante a las observaciones, pero también cubrían parte del Pirineo y extremo oriental de Lleida. Sin embargo, sobre Tarragona y el sur de Lleida apenas aparecían las precipitaciones asociadas a la línea de convergencia y el tren convectivo, con acumulaciones previstas inferiores a los $60 \mathrm{~mm} / 24 \mathrm{~h}$, con algún pequeño máximo de entre 100 y $120 \mathrm{~mm}$ en la última pasada disponible antes del episodio (12 UTC del día 22).

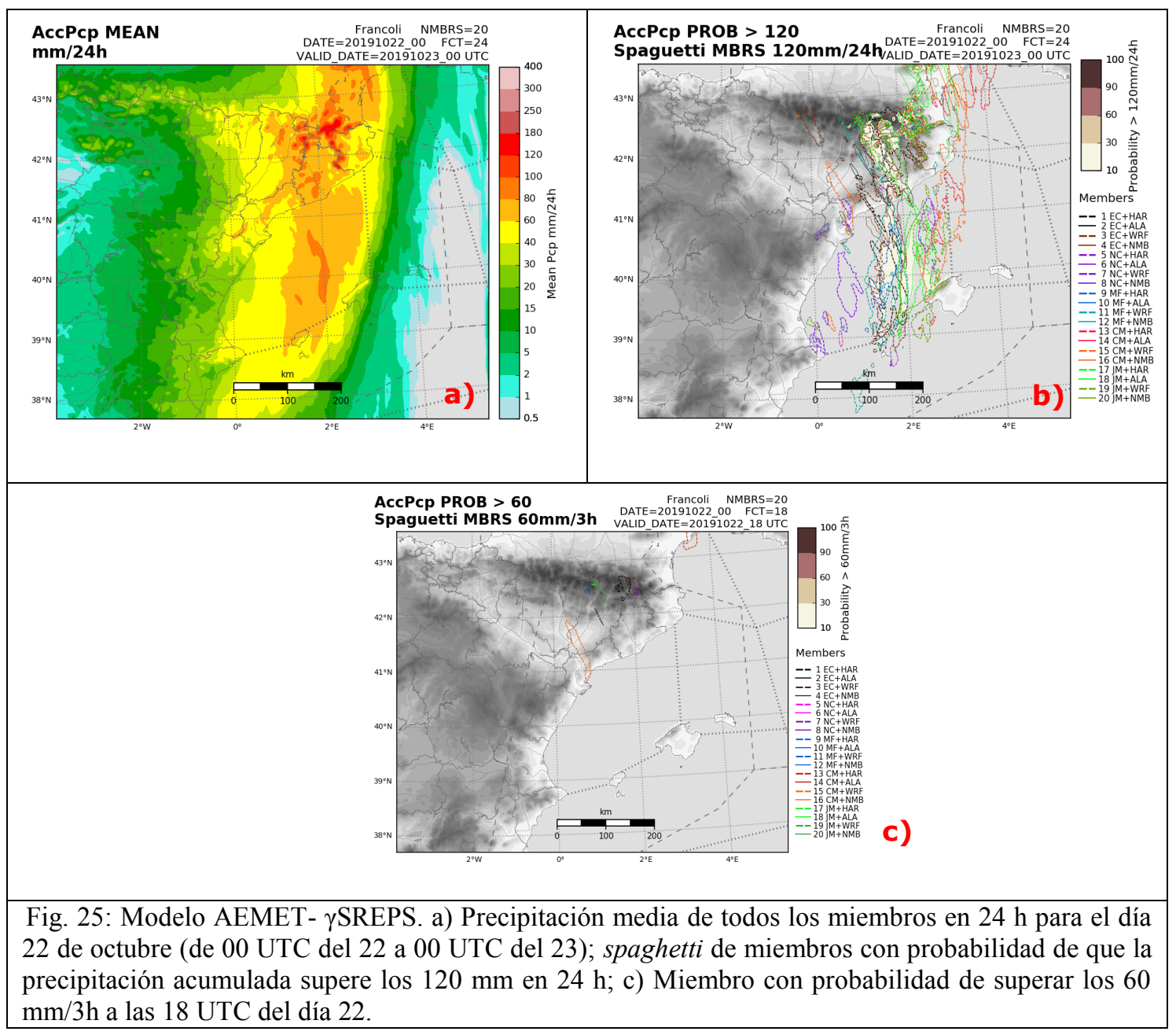


Por último, se realizó también un análisis de las salidas del ensemble multimodelo a corto plazo AEMET- $\gamma$ SREPS (fig. 25) y se comprobó que tampoco simuló muy bien la situación en lo que a precipitación se refiere. La mayor parte de los miembros del ensemble subestimaron la precipitación acumulada y era difícil extraer información (localización y valor) acerca de los máximos de precipitación ya que había bastante dispersión entre los 20 miembros. Tan sólo un miembro pareció intuir la línea de precipitación (ver fig. 25.c). La segunda parte del episodio, que afectó al nordeste de Cataluña durante el final del día 22 y la madrugada del 23, fue mejor prevista que la estructura convectiva que afectó a Tarragona y el sur de Lleida. 


\section{Conclusiones}

Se ha llevado a cabo un estudio del reciente episodio de lluvias muy intensas e inundaciones repentinas que tuvo lugar los días 22 y 23 de octubre de 2019 en Cataluña con el resultado de 4 personas fallecidas y dos desaparecidas y cuantiosos daños severos o, incluso, catastróficos. Este tipo de episodios de inundaciones repentinas producidas por precipitaciones muy intensas constituyen el mayor riesgo natural que afecta a los países mediterráneos, especialmente en la región noroeste de dicha cuenca. Este evento tuvo lugar en el marco sinóptico de una dana en niveles medios-altos que afectó a la península ibérica, así como la formación de una ciclogénesis en el entorno de Argelia y más tarde Baleares, que dieron lugar a convección profunda que afectó al mediterráneo occidental y especialmente el nordeste peninsular, donde se produjeron chubascos y tormentas de intensidad fuerte. La combinación de este contexto sinóptico con una serie de condiciones mesoescalares (aire húmedo e inestable marítimo de largo recorrido, orografía, etc.) dio lugar a la formación de una línea de convergencias mesoescalar que generó un efecto de tren convectivo de tormentas sobre el norte de la provincia de Tarragona, provocando lluvias de intensidad muy fuerte e incluso torrencial y la inundación repentina asociada a la avenida del río Francolí.

Mediante el análisis detallado de las predicciones de los modelos numéricos disponibles en el momento de generar la predicción y la emisión de avisos, se ha comprobado su relativa ineficiencia a la hora de representar, en este episodio concreto, tanto en la magnitud como en la ubicación precisa de los máximos de intensidad de precipitación. Tan sólo a través de un escrutinio de las herramientas de teledetección es posible inferir la magnitud del fenómeno, así como las características de las estructuras que se formaron y su potencial impacto. Una vez más se pone de manifiesto la importancia de la vigilancia y el nowcasting en la predicción de este tipo de eventos, sin restar relevancia a la experiencia del predictor y el conocimiento del terreno, pues tras este estudio ha quedado claro el rol crucial de la orografía, especialmente importante en el noroeste de la cuenca mediterránea.

Por último, cabe destacar también la necesidad de elaborar herramientas de nowcasting que combinen la predicción meteorológica con factores hidrológicos claramente involucrados tanto en la dimensión como en los impactos (exposición y vulnerabilidad) de este tipo de episodios. 


\section{Agradecimientos}

Se quiere expresar un especial agradecimiento a: la red de estaciones automáticas de Meteoclimatic por la cesión de imágenes de datos; el Ayuntamiento de l'Espluga de Francolí y el Arxiu Comarcal de la Conca de Barberà por su especial disposición y la aportación de numerosas imágenes de los impactos; Jesús Ortiz, la Associació per a la Conservació dels Ecosistemes Naturals y la Universidad Rovira i Virgili por la cesión de imágenes topográficas (Oda Cadiach, Institut Cartogràfic i Geològic de Catalunya (ICGC)); el club Camping Caravaning Aqua Alba por la cesión de imágenes de impactos del tornado de Gualba; David Gil y el equipo de AEMET- $\gamma$ SREPS por poner a disposición los campos necesarios para el caso de estudio.

También queremos agradecer la revisión realizada por el Comité Asesor de Selección de Publicaciones (CASP) de AEMET y la también detallada revisión realizada por Marc Berenguer, investigador del Centre de Recerca Aplicada en la Hidrometeorologia (CRAHI) y de la Universitat Politècnica de Catalunya (UPC). 


\section{Bibliografía}

Agència Catalana de l'Aigua (ACA), Departament de Territori i Sostenibilitat (Generalitat de Catalunya) (2019). Episodio de lluvias del 22 y 23 de octubre Cuencas internas de Cataluña. Jornada sobre el Estado de implantación de los planes de gestión del riesgo de inundación: lecciones aprendidas y retos pendientes.

Barrera, A., Llasat, M. C., y M. Barriendos (2006). Estimation of extreme flash flood evolution in Barcelona County from 1351 to 2005. Natural Hazards and Earth System Science, Copernicus Publications on behalf of the European Geosciences Union, 2006, 6 (4), pp.505-518. hal-00299319.

Chappell C. F. (1986). Quasi-Stationary Convective Events. In: Ray P.S. (eds.) Mesoscale Meteorology and Forecasting. American Meteorological Society, Boston, MA. 289-290.

Doswell, C. A. I. I. I., H. Brooks, and R. Maddox (1996). Flash flood forecasting: An ingredient-based methodology. Wea. Forecasting, 11, 560-581.

Gilabert, J. y M. C. Llasat (2018). Circulation weather types associated with extreme flood events in Northwestern Mediterranean. International Journal of Climatology, 38. 1864-1876. 10.1002/joc.5301.

Jansà, A, Alpert, P., Arbogast, P., Buzzi, A., Ivancan-Piek, B., Kotroni, V., Llasat, M. C., Ramis, C., Richard, E., Romero, R., Speranza, A. (2014). MEDEX: a general overview. Nat. Hazards Earth Syst. Sci. 14, 1965-1984.

Llasat, M. C., Llasat-Botija, M., Petrucci, O., Pasqua, A. A., Rosselló, J., Vinet, F., and Boissier, L. (2013). Towards a database on societal impact of Mediterranean floods within the framework of the HYMEX project, Nat. Hazards Earth Syst. Sci., 13, 13371350, https://doi.org/10.5194/nhess-13-1337-2013.

Llasat, M.C., Marcos, R., Llasat-Botija, M., Gilabert, J., Turco, M., y P. QuintanaSeguí (2014). Flash flood evolution in North-Western Mediterranean. Atmospheric Research, doi:10.1016/j.atmosres.2014.05.024.

Llasat, M.C., Marcos, R.,Turco, M., Gilabert, J. y M. Llasat-Botija (2016). Trends in flash flood events versus convective precipitation in the Mediterranean region: the case of Catalonia. J. Hydrol, 541:24-37.

Martín-Vide, J. P., Ferrer, C., Ruiz, R., Berenguer, M., Corral, C., Prats, A., Bateman, A., Sosa, R., Marín, B. y S. Gómez (2020). Anàlisi de la crescuda del Francolí del 22 d'octubre de 2019. Informe elaborado por la Agència Catalana de 1'Aigua (Barcelona). $27 \mathrm{pp}$.

Ortiz, J., Blay, J., Sierra, J., Roig, N., Perez-Paricio, A., Buqueras, X. y M. Schuhmacher (2014). La vida al riu Francolí. Els humans i els sistemes aquàtics. Universitat Rovira i Virgili, Publicacions URV. ISBN: 978-84-695-9177-2. 
